\title{
Resolving intergeneric relationships in the aervoid clade and the backbone of Ptilotus (Amaranthaceae): Evidence from whole plastid genomes and morphology
}

\author{
Timothy A. Hammer, ${ }^{1}$ Xiao Zhong, ${ }^{2}$ Catherine Colas des Francs-Small, ${ }^{2}$ Paul G. Nevill, ${ }^{3}$ Ian D. Small ${ }^{2}$ \\ \& Kevin R. Thiele ${ }^{1}$ \\ ${ }^{1}$ School of Biological Sciences, Faculty of Science, The University of Western Australia, Crawley, Western Australia, \\ 6009, Australia \\ ${ }^{2}$ ARC Centre of Excellence in Plant Energy Biology, The University of Western Australia, Crawley, Western Australia, \\ 6009, Australia \\ ${ }^{3}$ ARC Centre for Mine Site Restoration, School of Molecular and Life Sciences, Curtin University, Bentley, Western \\ Australia, 6102, Australia \\ Address for correspondence: Timothy A. Hammer, timothy.hammer@research.uwa.edu.au
}

\begin{abstract}
The informally named "aervoid clade" in Amaranthaceae includes $\sim 134$ species in five genera: Ptilotus ( 120 spp.), Aerva (11 spp.) and the monotypic Nothosaerva, Omegandra, and Kelita. The relationships of the small aervoid genera to the large genus Ptilotus, and relationships between major clades within Ptilotus, are poorly resolved. The aims of this study were to: (1) elucidate relationships between genera and within Ptilotus using a phylogenomic approach; (2) identify morphological characters within each genus to help delimit generic boundaries; and (3) provide an updated taxonomic framework for the aervoids. A well-supported coding DNA sequence (CDS) phylogeny was constructed for 36 aervoid and 5 outgroup species based on 69 gene sequences derived from assembled whole-plastid genomes. The CDS tree was used to constrain relationships on a larger phylogeny based on Sanger-sequenced ITS and matK for 135 taxa, comprising near-comprehensive sampling within the aervoids. Both datasets were analysed using maximum likelihood and Bayesian inference. Morphological characters were assessed from herbarium specimens. Our study demonstrates that Aerva is polyphyletic; this is resolved by reinstating Ouret and erecting a new genus, Paraerva. Kelita is found to be deeply nested within Ptilotus and is formally synonymised. The well-resolved phylogeny of Ptilotus presented here will inform future studies in biogeography and character evolution. A taxonomic treatment is provided for all aervoid genera, and new combinations are made.
\end{abstract}

Keywords Amaranthaceae; Caryophyllales; new genus; nomenclature; phylogenomics; Ptilotus; taxonomy

\section{INTRODUCTION}

Amaranthaceae Juss. s.str. (i.e., excluding Chenopodiaceae Vent.) is a family of approximately 79 genera and 800 species within the Caryophyllales Berchtold \& J.Presl (see Hernández-Ledesma \& al., 2015 for a recent treatment). The aervoids (Fig. 1) are an informal species-rich clade within Amaranthaceae that includes five genera: Ptilotus R.Br. ( 120 spp.), Aerva Forssk. (11 spp.), and the monotypic Kelita A.R.Bean, Nothosaerva Wight and Omegandra G.J.Leach \& C.C.Towns. (Leach \& al., 1993; Bean, 2010; Hammer \& al., 2017). Taxonomic and morphological diversity within the aervoids is concentrated in Australia (Kelita, Omegandra and Ptilotus); Aerva and Nothosaerva are native to Africa and South Asia. A comprehensive taxonomic treatment of the aervoids has been made more urgent by a recent initiative to develop a global synthesis for the Caryophyllales (Hernández-Ledesma \& al., 2015; see also http://www.caryophyllales.org).

Endlicher (1837) provided an early family-level classification for the Amaranthaceae, dividing the family into three tribes based on ovary and anther characters. Genera assigned to tribe Gomphreneae (i.e., Gomphrena L. and allies) possessed uniovulate ovaries and unilocular anthers; tribe Achyrantheae (i.e., Achyranthes L. and allies; Amarantheae in Moquin-Tandon, 1849) included genera with uniovulate ovaries and bilocular anthers; while tribe Celosieae (i.e., Celosia L. and allies) included genera with multi-ovulate ovaries and bilocular anthers. Endlicher further divided tribe Achyrantheae into four subtribes: Aervinae (as "Aerveae"), Amaranthinae ("Amarantheae"), Desmochaetinae ("Desmochaeteae") and Polycneminae ("Polycnemeae"). The genera known to Endlicher and currently included in the aervoids (Aerva, Ptilotus and the now subsumed genus Trichinium R.Br.) were included in subtribe Aervinae along with Achyranthes, Centrostachys Wall., Nyssanthes R.Br. and Psilotrichum Blume, based on their uniovulate ovaries, bilocular anthers, 3-bracteate flowers (1 bract and 2 lateral bracteoles), and indehiscent fruits. 

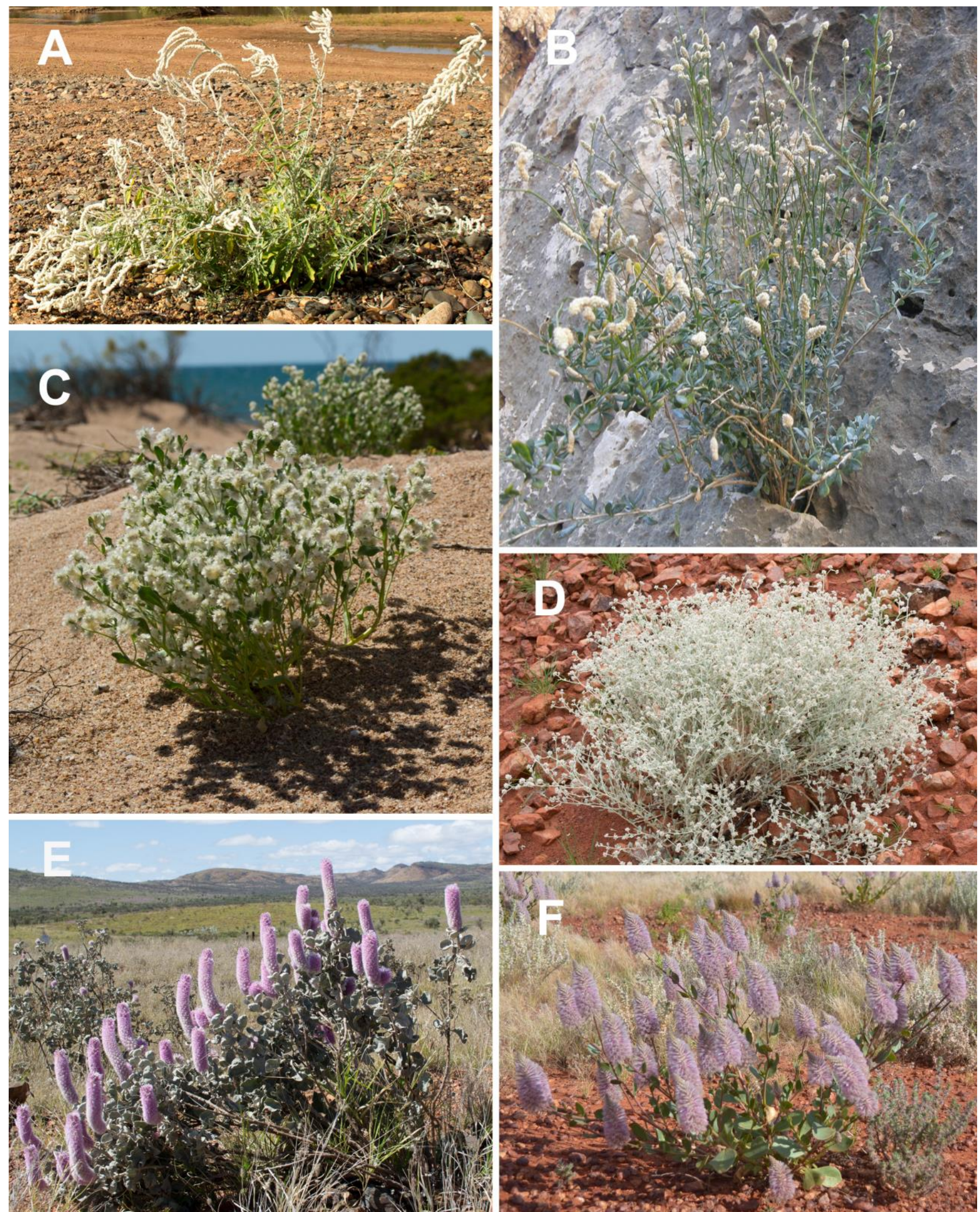

Fig. 1. Species representing major clades within the aervoids. A, Aerva javanica; B, A. microphylla; C, Ptilotus villosiflorus; D, P. astrolasius $; \mathbf{E}, P$. rotundifolius $; \mathbf{F}, P$. exaltatus. — Photos taken by T. Hammer in Western Australia (A, C-E) and South Australia (F) and by Alena Vydrova and Vit Grulich on Socotra (B).

Bentham \& Hooker (1880) followed Endlicher (1837) and Moquin-Tandon (1849) in dividing the family into the tribes Amarantheae (= Achyrantheae), Celosieae, and Gomphreneae, but differed in the subtribal classification of Amarantheae, establishing subtribe Amaranthinae ("Euamarantheae") for taxa with an erect ovule and downwardly directed radicle, and subtribe Achyranthinae ("Achyrantheae") for taxa with a pendulous ovule and upwardly directed radicle, the aervoid genera being placed in the latter. 
Schinz (1893) established the most widely accepted and long-standing classification of Amaranthaceae, largely based on the preceding classifications but adding a subfamily rank (establishing subfam. Amaranthoideae for taxa with bilocular anthers and subfam. Gomphrenoideae for taxa with unilocular anthers). Subfamily Amaranthoideae was divided into the tribes Amarantheae (one-seeded) and Celosieae (multi-seeded), the former including two subtribes following Bentham \& Hooker (1880), but with "Euamarantheae" renamed as Amaranthinae. Schinz placed the aervoid genera known at that time (Aerva, Nothosaerva and Ptilotus) in subfamily Amaranthoideae, tribe Amarantheae and subtribe Achyranthinae, along with 12 other genera (e.g., Achyranthes and Arthraerua (Kuntze) Schinz). Townsend (1993), in the most recent treatment of the family, largely followed Schinz's classification, and accepted 38 genera in subtribe Aervinae.

The advent of molecular phylogenies allowed these classifications to be tested and have indicated that most infra-familial taxa of previous authors (including Amaranthoideae, Amarantheae and Aervinae) are paraphyletic (e.g., Kadereit \& al., 2003; Müller \& Borsch, 2005; Sage \& al., 2007). In anticipation of a substantially revised, formal infra-familial classification, Müller \& Borsch (2005) established informal clades within the family, including the achyranthoids, aervoids, amaranthoids and gomphrenoids (for clades centred on Achyranthes, Aerva, Amaranthus L. and Gomphrena respectively). They recovered two clades within the Aervinae of previous authors, one comprising Aerva, Nothosaerva and Ptilotus and the other comprising Achyranthes and related genera (their achyranthoids). The achyranthoids, aervoids and gomphrenoids are together sister to the amaranthoids and Celosieae, the only monophyletic tribe recovered in Amaranthoideae (Kadereit \& al., 2003; Müller \& Borsch, 2005). We continue to use these informal clade names while awaiting an updated classification for the family.

Early, family-wide phylogenetic studies included relatively few species within genera, and often relatively few genera. Kadereit \& al. (2003) included Aerva javanica (Burm.f.) Juss. ex Schult. and Ptilotus manglesii (Lindl.) F.Muell. as the only representatives of the aervoids and did not resolve Aerva and Ptilotus as a clade, instead placing them in an unresolved polytomy with the achyranthoids and gomphrenoids. This lack of resolution was perhaps due to the lack of informative characters for these taxa on the $r b c L$ marker. Müller \& Borsch (2005) included A. javanica, N. brachiata, P. manglesii and P. obovatus (Gaudich.) F.Muell. The two Ptilotus species were resolved as sisters with $100 \%$ bootstrap support, but relationships between the three genera were unresolved.

Thiv \& al. (2006), in an attempt to assess phylogenetic relationships within Aerva, included multiple accessions for 10 of the 12 species that they recognised within the genus (i.e., A. artemisioides Vierh. \& O.Schwartz, A. congesta Balf.f, A coriacea Schinz, A. javanica (Burm.f.) Juss. ex Schult., A. lanata (L.) Juss. ex Schult., A. leucura Moq., A. microphylla Moq., A. revoluta Balf.f., A. sanguinolenta (L.) Blume and A. triangularifolia Cavaco, excluding only A. glabrata Hook.f. and A. humbertii Cavaco due to a lack of suitable material for sequencing). They used two Ptilotus species as outgroups. In their ITS, mat $K$ and $a t p B-r b c L$ phylogenies, two clades of Aerva were resolved and informally named clades "A" and "B" (referred to here as "clade I" and "clade II" respectively). Clade I of Aerva included three subclades on a polytomy: A. artemisioides, A. javanica and the two Socotran endemics A. microphylla and A. revoluta. Clade II included all other Aerva species sampled. Because their tree was rooted on Ptilotus and did not sample more widely within the family, the monophyly of Aerva was not tested.

Sage \& al. (2007) sampled widely for a family-level phylogeny based on $t r n K / m a t K$ sequences and provided the first indication that Aerva was paraphyletic with respect to Ptilotus (with Aerva leucura and A. sanguinolenta forming a highly supported clade with P. manglesii and P. obovatus, while A. javanica and $N$. brachiata resolved separately as a clade with weak support). Sage $\&$ al. (2007) also confirmed the monophyly of the aervoids.

Hammer \& al. (2015) reconstructed the phylogeny of 87 species of Ptilotus using ITS and matK. Sampling covered the morphological and geographic diversity of the genus, and included three species of Aerva, two species of Gomphrena, Achyranthes aspera L. and Amaranthus caudatus L. (on which the tree was rooted). Aerva was confirmed as paraphyletic in this study, with A. lanata resolving as more closely related to Ptilotus than either A. javanica or A. artemisioides, albeit with weak support. Ptilotus was strongly supported as monophyletic. Four major clades (informally named A-D) were resolved within Ptilotus. The largest of these (D; 73\% of species) comprised four subclades (D1-D4), related by a polytomy. Hammer \& al. (2015) 
speculated that Ptilotus had radiated rapidly, probably after its ancestor arrived on the Australian continent following a divergence in Southeast Asia from a common ancestor with one of the clades of Aerva.

A follow-up study by Hammer \& al. (2017) reconstructed an ITS and trnK/matK phylogeny for all species of Aerva that had been accepted by Thiv \& al. (2006), as well as extra gomphrenoid and achyranthoid taxa. This study placed one species, A. artemisioides, in a position sister to the rest of the achyranthoids, distant from the aervoids. A morphological examination revealed that A. artemisioides has an unusual combination of characters, unlike any aervoid or any other known genus in Amaranthaceae: accordingly, the genus Wadithamnus T.Hammer \& R.W.Davis was erected to accommodate it. With W. artemisioides removed, the remaining species of Aerva were still paraphyletic with respect to Ptilotus.

The phylogenies of Hammer \& al. (2015) and Hammer \& al. (2017), based on Sanger sequencing of a small number of markers, provided a good understanding of major clades within the aervoids. However, relationships between clades were in many cases poorly supported, precluding a robust taxonomic solution to the paraphyly of Aerva, and the monotypic genera Kelita and Omegandra were not included.

To address this, we present here a nearly taxon-complete phylogeny of the aervoids and use next-generation sequencing of the chloroplast genome to resolve, with high support, backbone relationships among clades. Such an approach has been utilized successfully to resolve backbone relationships within various plant families where phylogenies based on Sanger-sequenced traditional markers were inadequate (e.g., Ma \& al., 2014; Gardner \& al., 2016; Williams \& al., 2016; Tonti-Filippini \& al., 2017), particularly when rapid radiations obscure relationships (Wei \& al., 2017; Léveillé-Bourret $\&$ al., 2018). This is the most comprehensive and strongly supported phylogeny of the aervoids to date. It provides a basis for a generic taxonomic treatment of the aervoids and will inform future biogeographic analyses and studies into the evolution of floral characters and pollination syndromes, especially within Ptilotus.

\section{MATERIALS AND METHODS}

Taxon sampling and DNA extraction. - Phylogenetic analyses were conducted on three datasets: (1) coding DNA sequences (CDS) of the plastid genome for 41 selected taxa, and Sanger sequences of (2) ITS for 128 taxa, and (3) $m a t K$ for 135 taxa (sequencing of ITS failed for some taxa). The Sanger sequencing section of this study incorporated all ITS and $m a t K$ sequences from Hammer \& al. (2015), some of the outgroup species used in Hammer \& al. (2017), and an additional 26 species not previously sequenced. ITS and matK were used because they have been widely sequenced in previous studies, have been shown by Hammer \& al. $(2015,2017)$ to be highly congruent, and because of their complementary nature in resolving deep and shallow nodes (Hammer \& al., 2015). A near-comprehensive sampling of the aervoids included 112 (of $~ 120$ ) Ptilotus species, 10 of 11 recognised Aerva species (i.e., excluding only the rare Madagascan A. humbertii), and the monotypic genera Nothosaerva, Omegandra and Kelita. In addition to the aervoids, 10 outgroup species were chosen to provide broad representation of the achyranthoids, gomphrenoids and amaranthoids. A full list of accessions used in the ITS and matK analyses is provided in Appendix 1.

Sampling for the plastid CDS phylogeny included 30 Ptilotus species, Aerva javanica, A. glabrata and A. microphylla (representing the major clades of Aerva from Hammer \& al., 2017), Kelita uncinella A.R.Bean and Omegandra kanisii G.J.Leach \& C.C.Towns. Outgroup species were Gomphrena affinis subsp. pilbarensis J.Palmer and Gomphrena cunninghamii (Moq.) Druce representing the gomphrenoids, Achyranthes aspera L. and Alternanthera nodiflora R.Br. representing the achyranthoids, and Amaranthus cuspidifolius Domin representing the amaranthoids. Most of the included Ptilotus species and the Gomphrena outgroups were sequenced as part of a project to sequence full chloroplast genomes for plants from the Pilbara region of Western Australia (see https://s3-ap-southeast-2.amazonaws.com/pilbara-cpt-website/index.html). As this region is home to approximately one-third of Ptilotus species, representing every major clade in the genus (Hammer \& al., 2015), adequate coverage for resolving the backbone could be achieved from this narrow geographic sampling. A full list of accessions used in the CDS dataset is provided in Appendix 2.

DNA was extracted from silica-dried leaf material collected in the field, and from herbarium specimens at AD, BRI, E, PE and PERTH. Approximately $20 \mathrm{mg}$ of dried plant material was pulverized for 1 minute in a minibead beater. Total genomic DNA was extracted using DNeasy Mini Plant Kits (Qiagen, Valencia, California, 
U.S.A.) following the manufacturer's protocol. DNA quantity and quality were assessed using a Qubit dsDNA HS Assay Kit (ThermoFisher Scientific, Waltham, Massachusetts, U.S.A.) and agarose gel electrophoresis.

NGS sequencing, genome assembly, annotation and alignment. - A Covaris S220 sonicator was used to shear 200 ng of DNA into 500 base pair (bp) fragments. Libraries were prepared with an Illumina TruSeq Nano DNA LT Library Preparation Kit according to the manufacturer's directions, their sizes checked on a 4200 TapeStation System (Agilent Technologies, Santa Clara, California, U.S.A.), quantified with a KAPA SYBR FAST Universal qPCR Kit (Sigma-Aldrich, St. Louis, Missouri, U.S.A.), pooled and run on a MiSeq sequencer (Illumina, San Diego, California) using a MiSeq Reagent Kit v3 (Illumina).

Sequence pre-processing included the following: removing adapter sequences using Cutadapt v.1.9.1 (Martin, 2011), correcting read errors using SPAdes v.3.6.1 (Bankevich \& al., 2012) and merging overlapping pairedend reads using BBMerge v.8.82 (Bushnell \& al., 2017). The clean reads were independently assembled into circular or fragmented contigs with the de novo assemblers NOVOPlasty v.2.5.9 (Dierckxsens \& al., 2016), ORGanelle ASeMbler v.2.2 (Org.asm; https://pythonhosted.org/ORG.asm/), and Velvet v.1.2.08 (Zerbino \& Birney, 2008). Velvet was run with k-mer values between 51 and 111 and a coverage cut-off of 10. Org.asm was run with the parameters minread $=5$, smallbranches $=15$, and seed $=$ protChloroArabidopsis (i.e., chloroplast protein sequences of Arabidopsis thaliana (L.) Heynh.).

In addition, a reference-guided approach was utilized to order, orient and merge contigs to produce a single sequence draft genome, if needed, based on the alignment between the contigs and a high-quality reference chloroplast genome from the closest related species. Pair-wise alignments were generated using MUMmer v.3.23 (Kurtz \& al., 2004). The assemblies were refined further and verified by automatically analysing consistency between original reads and these draft genomes using Pilon v.1.16 (Walker \& al., 2014), and by visually inspecting for discrepancies between them and among multiple assembled sequences of the same organism using Geneious v.9.1.8 (Kearse \& al., 2012). Finally, the best assembly for each species was selected by considering accuracy, integrity and continuity at base level. Mapping of reads to assembled sequences was carried out with BWA v.0.7.15 ( $\mathrm{Li}, 2013)$, and multiple sequence alignments using MAFFT v.7.273 (Katoh \& Standley, 2013). Genomes were annotated by the "Transfer Annotations" function in Geneious using the previously published Amaranthus hypochondriacus L. annotation as a reference, with manual corrections.

Coding regions were extracted from the annotated plastid genomes and aligned separately using MAFFT prior to concatenation using Geneious. The best partitioning scheme for the CDS data was found using PartitionFinder v.2.1.1 (Lanfear \& al., 2016), with all genes and codon positions as separate data blocks and using the "greedy" search algorithm.

Sanger sequencing and alignment. - Amplification of ITS (ITS1, 5.8S, ITS2) was accomplished using ITS5A (forward) and 26S-25R (reverse) primers (Motley \& al., 2005). Primers used to amplify matK were matK-AF (Thiv \& al., 2006) and matK1R (Sang \& al., 1997). Each $50 \mu 1$ PCR reaction was performed using $5 \mu \mathrm{l} 10 \mathrm{x}$ buffer, $0.5 \mu \mathrm{l} \mathrm{dNTPs}(2.5 \mathrm{mM}), 41.25 \mu \mathrm{l}$ nuclease-free water, $0.25 \mu \mathrm{l}$ Taq, $0.5 \mu 1$ of each $10 \mu \mathrm{M}$ primer, and $2 \mu \mathrm{DNA}$ template. Thermocycler programs for amplification were as outlined in Hammer \& al. (2015). Sequencing was performed by Macrogen (Seoul, Korea). Sequence chromatograms were manually edited using Geneious. Sequences were aligned using the default settings of MAFFT, and aligned sequences inspected and manually adjusted as needed. The best nucleotide substitution models were determined using jModelTest2 v.2.1.6 (Darriba \& al., 2012).

Phylogenetic analyses. - Bayesian inference (BI) was performed using MrBayes v.3.2.2 (Ronquist \& al., 2012). Analyses were run for 15 million Markov chain Monte Carlo (MCMC) generations with trees sampled every 1000 generations. Analyses were conducted on partitioned datasets with appropriate substitution models determined by jModelTest 2 for each partition. Completion was determined by the average standard deviation of split frequencies falling below 0.01 . Trace files generated by the MCMC runs were analysed using Tracer v.1.6 to determine adequate convergence and mixing (Rambaut \& Drummond, 2007). The initial 25\% of topologies before reaching likelihood stationarity were discarded; $50 \%$ majority-rule consensus trees were constructed to summarize the remaining topologies. Maximum likelihood (ML) analyses were implemented on RAxML v.8.2.10 (Stamatakis, 2014), with options for GTRGAMMA and proportion of invariable sites estimation options enabled, and run for 1000 bootstrap iterations. 
Hammer \& al. (2015) showed that ITS and matK were congruent and could be concatenated using similar taxon sampling. For this reason, and because a few species could not be sequenced for both markers, a congruence analysis was not performed and the ITS and matK sequences concatenated. The CDS tree was used as a topological constraint for analyses of the concatenated Sanger dataset. Topological constraints for the MrBayes block were generated using the paleotree R package (Bapst, 2012). MAFFT alignments, jModelTest2 and BI and ML analyses were conducted on the Cyberinfrastructure for Phylogenetic Research (CIPRES) portal (Miller \& al., 2010). Bootstrap values were summed using SumTrees v.3.3.1 in the DendroPy v.3.12.0 python package (Sukumaran \& Holder, 2010). CDS trees were rooted at Amaranthus cuspidifolius and Sanger trees at Amaranthus caudatus.

Morphological examinations. - Specimens from AD, BRI, E, PE and PERTH (listed in Appendix 3), representing all major clades of aervoids, were morphologically examined. Flowers for dissection were rehydrated in hot water with a little detergent. Due to the small size of flowers in many species, a JEOL JCM5000 NeoScope bench-top scanning electron microscope (SEM) at the Western Australian Herbarium (PERTH) was used to image whole flowers and reproductive parts. Multiple gynoecia were obtained from herbarium specimens from bisexual or female individuals of each species, mounted on stubs using carbon tape, and coated with gold for two minutes using a JEOL Smart Coater.

Some terminology used in the Discussion and Taxonomic treatment sections in this paper is different from that conventionally used for this group, particularly within Australia. The term "staminal cup appendages" is used here in favour of "pseudostaminodes", as this more aptly describes these projections from the staminal cup, which are ontogenetically different from staminodes. We have adopted "sepals" instead of the conventional "tepals" to describe the perianth in this group, following recent studies (e.g., Ronse De Craene, 2013) that uniseriate perianths in the Caryophyllales are calycine in origin (see also Borsch \& al., 2018).

\section{RESULTS}

CDS and Sanger sequencing datasets. - The aligned CDS dataset comprised 69 genes with a combined length of 51,996 bp (suppl. Appendix S1). The aligned ITS region comprised $773 \mathrm{bp}$, the aligned mat $K$ region comprised $798 \mathrm{bp}$, and the combined ITS + matK dataset was $1571 \mathrm{bp}$ long (suppl. Appendix S2). Amplification of ITS failed for seven species, which were therefore represented by matK sequences alone. Bayesian and Akaike information criteria (BIC and AIC) in jModelTest2 agreed that the best nucleotide substitution models for use in MrBayes were GTR $+\mathrm{I}+\Gamma$ for ITS and GTR $+\Gamma$ for $m a t K$.

Phylogenetic analyses. - All phylogenetic analyses gave largely congruent results. Major clades resolved on the CDS phylogeny (Fig. 2) agreed with those resolved from previous studies (Hammer \& al., 2015, 2017) and with the unconstrained ML and BI ITS + matK phylogenies (suppl. Figs. S1, S2). The constrained ITS + matK phylogeny (henceforth "constrained tree"; Fig. 3) maintained the relationships resolved in the CDS phylogeny. Species in Amaranthus, Alternanthera and Gomphrena in the CDS dataset were represented in the ITS + matK dataset by different species in the same genus; this did not affect intergeneric relationships on the tree. Because topological constraints are handled differently in MrBayes and RAxML, BI posterior probabilities (PP) and ML bootstrap support (BS) on the constrained branches (bolded in Fig. 3) vary dramatically in some cases. In MrBayes, the constraints are applied universally to the MCMC runs, with only topologies that agree with the constraints being considered, ensuring higher PP on the branches for those constrained relationships. In RAxML, the ML search tree is constrained to the topology of an input tree (i.e., the CDS tree), but no constraint is applied when bootstrapping the trees. Therefore, the BS on constrained nodes reflects support in the unconstrained concatenated Sanger dataset. In both analyses, unconstrained taxa are free to change position on the tree during the analysis. 


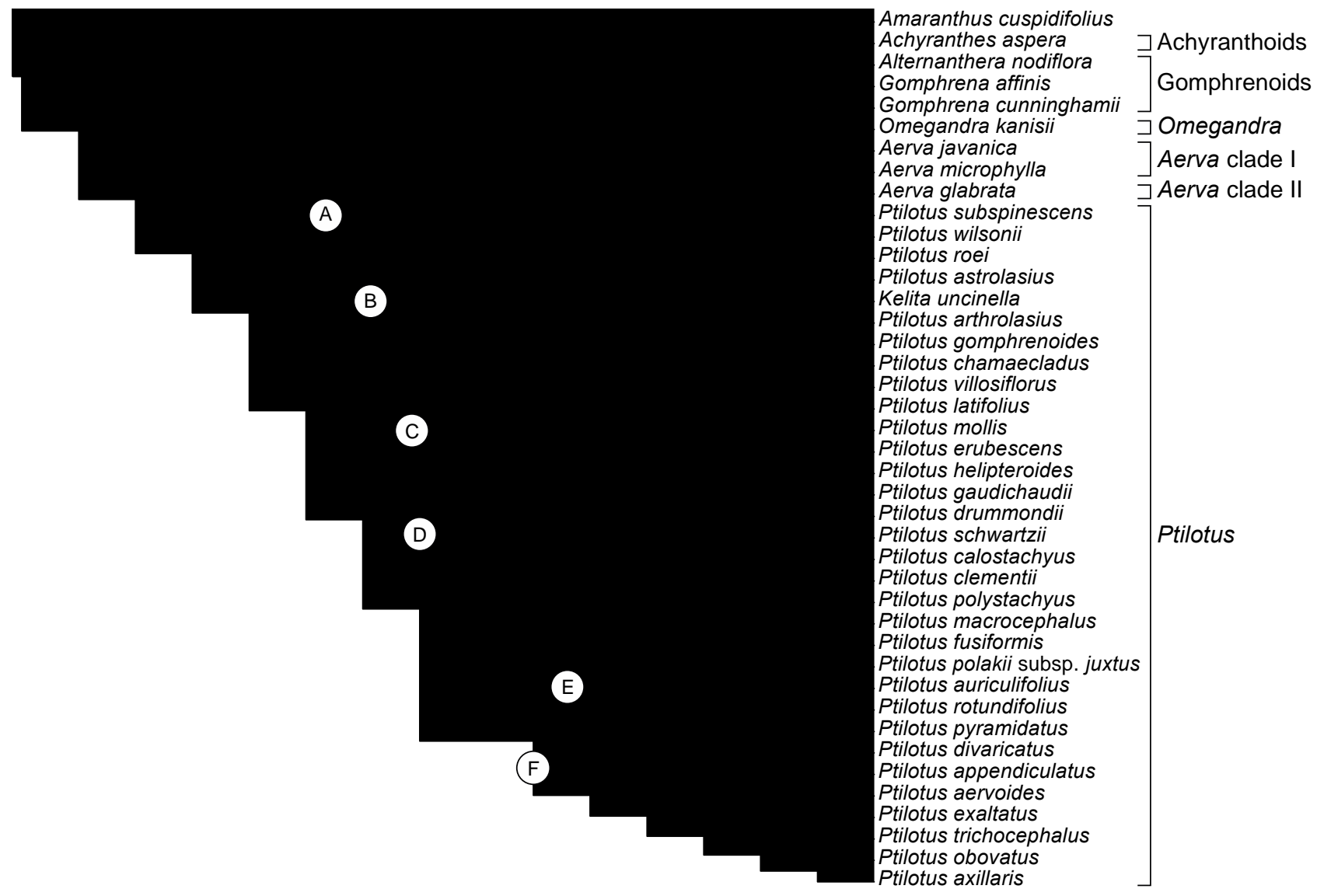

Fig. 2. The MrBayes 50\% majority census tree of the CDS dataset with support values above the branches (BI posterior probabilities/ML bootstrap percentages). Asterisks (*) indicate maximum support values (1.00 or 100\% respectively). Major clades outside of Ptilotus indicated on the right and major clades within Ptilotus (A-F) are indicated on the branches.

Intergeneric relationships. - The aervoids are well supported as monophyletic (1.00/100) on the CDS phylogeny (Fig. 2) and comprise three major clades: the "basal aervoids" (represented by $O$. kanisii sister to the Aerva clade I taxa A. javanica and A. microphylla); Aerva clade II (represented by A. glabrata); and Ptilotus including Kelita. In the constrained tree (Fig. 3), the basally branching aervoid clade is also well supported, but the placement of $N$. brachiata within this clade with poor support causes it to collapse to a polytomy comprising $O$. kanisii, $N$. brachiata, A. javanica, and a strongly supported sister pair of the Socotran species A. microphylla and A. revoluta (1.00/100). The poor placement of $N$. brachiata may be because repeated attempts to extract and sequence ITS from herbarium specimens of this species failed.

Aerva clade II is strongly supported as monophyletic (1.00/99), and sister to Ptilotus (1.00/99). Relationships within the clade are well resolved. One accepted species, the Madagascan endemic A. humbertii, was unavailable for sequencing for this study but can be confidently placed in this clade, along with the other species endemic to Madagascar (i.e., A. coriacea and A. triangularifolia), based on its morphology.

Relationships within Ptilotus. - Ptilotus clades A, B and C of Hammer \& al. (2015) are recovered on the CDS phylogeny with good support (Fig. 2). Clades A and C were each represented in the CDS tree by one of the three species in each clade ( $P$. subspinescens R.W.Davis and P. mollis Benl respectively), and no new species sampled were placed within these clades. Relationships within clade B recovered by Hammer \& al. (2015) are also recovered here (with the inclusion of newly sampled species; see Appendix 1). The nine species from clade B on the CDS phylogeny resolves the clade's backbone, and strongly supports the inclusion of Kelita uncinella within Ptilotus and in this clade. Only the P. conicus R.Br. species group, comprising seven species from northern Australia, was not represented on the CDS phylogeny. The relationships of these northern species were nevertheless well supported (1.00/82) in the constrained phylogeny, where they resolved with strong PP support (1.00/67) as a clade sister to an arid clade comprising P. astrolasius F.Muell. and three other species, mostly from the Pilbara region of Western Australia (Fig. 3). A group of tropical species from northern Western Australia and the Northern Territory (P. lanatus A.Cunn. ex Moq., P. rotundatus Benl, $P$. lophotrichus Benl and $P$. comatus Benl) which were not sequenced in Hammer \& al. (2015), were resolved 
as monophyletic (1.00/82). This tropical clade is nested within a chiefly Eremean clade (e.g., P. arthrolasius, $P$. gomphrenoides F.Muell. ex Benth.), rather than being more closely related to the $P$. conicus clade.

This study provides significantly improved backbone resolution within Ptilotus for clades D, E and F, which in Hammer \& al. (2015) formed an unresolved polytomy with P. declinatus Nees. Ptilotus erubescens, a species from South Australia that shares a strong morphological affinity with the Western Australian species $P$. declinatus, was sequenced for the CDS phylogeny and resolved as sister to the rest of clade D (1.00/97). On the constrained phylogeny, P. erubescens is sister to P. declinatus, with P. barkeri Benl sister to both (1.00/100), these three species comprising a position sister to the rest of clade D. A small clade of 10 species, including P. drummondii F.Muell., P. leucocoma (Moq.) F.Muell. and close relatives, are newly resolved on the constrained phylogeny $(0.98 / 56)$.

Clade E includes two subclades (comprising P. auriculifolius (Moq.) F.Muell. and allies, and P. polakii F.Muell. and allies, respectively) that are newly resolved as sisters (1.00/95 and 1.00/100 respectively). The subclade with P. polakii includes a few species (e.g., P. parvifolius (F.Muell.) F.Muell.) newly sequenced for this study, but as only one taxon (i.e., P. polakii subsp. juxtus Lally) could be included in the CDS dataset, the interspecific relationships between these close and morphologically similar species could not be resolved. This subclade has been previously referred to as the "Ptilotus parvifolius complex" (e.g., Lally, 2008). Most species in this subclade are long-lived rigid shrubs, which occur in arid regions of Australia. The related P. auriculifolius species group includes the arid-zone herb P. auriculifolius and shrubs P. rotundifolius (F.Muell.) F.Muell. and P. marduguru Benl, which are sister to a group of species native to the biodiversity hotspot of the Southwest Australian Floristic Region (except for P. symonii Benl from southeastern Western Australia and southwest South Australia and the putative new species P. sp. Arckaringa (D.J.Duval 1958) from the Lake Eyre region of South Australia). It includes the threatened species P. pyramidatus (Moq.) F.Muell., known from only one population in the Perth metropolitan area, Western Australia (Davis, 2012).

Clade F was represented by six species on the CDS phylogeny (Fig. 2). Ptilotus appendiculatus Benl was resolved at the base of the clade in the CDS phylogeny with good support. The relationship of $P$. aervoides (F.Muell.) F.Muell. with the remaining species is ambiguous due to a poorly supported node (0.68/62). The constrained tree has better backbone support than in Hammer \& al. (2015), however many of the relationships still need to be fully resolved, particularly within the derived group that includes $P$. axillaris (Benth.) F.Muell.

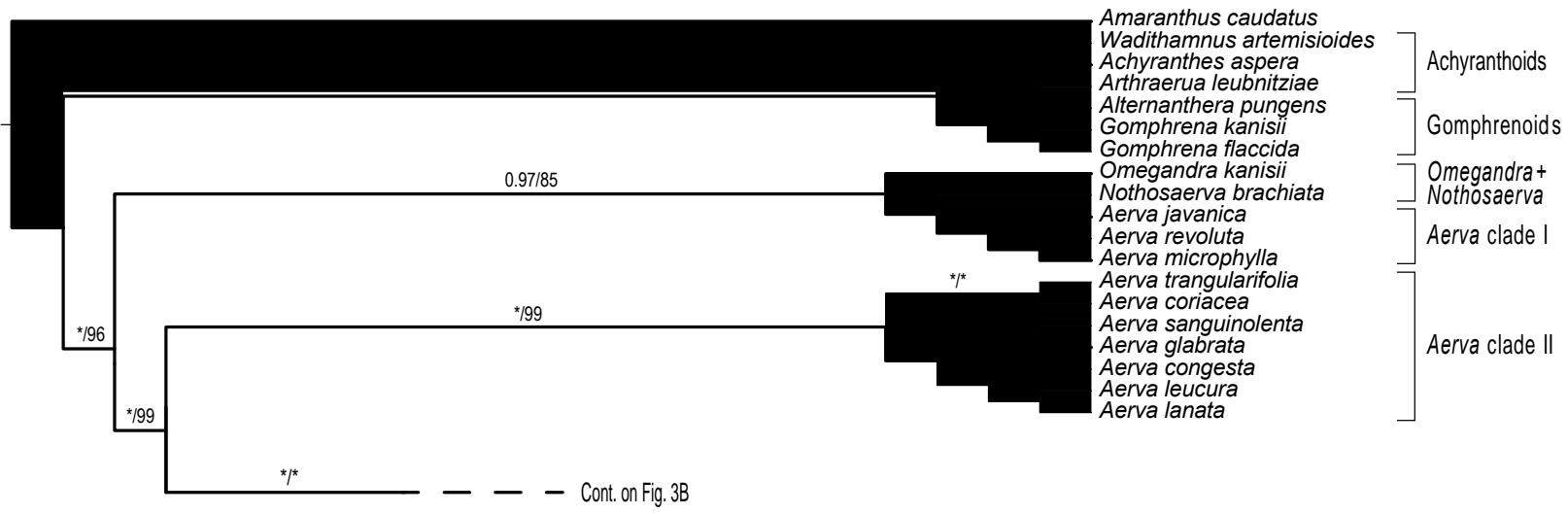

Fig. 3. The MrBayes $50 \%$ majority census tree of the Sanger ITS + matK dataset with support values above branches (BI posterior probabilities/ML bootstrap percentages). A, The whole tree with Ptilotus collapsed and major clades indicated on the right; $\mathbf{B}$ (next page), The expanded tree of Ptilotus with major clades of Ptilotus (A-F) indicated on the branches. Asterisks $(*)$ indicate maximum support values (1.00 or 100\% respectively) and a hyphen (-) indicates ML support below 50\%. Branches in bold indicate relationships resolved in the CDS tree and the topological constraints implemented in the analyses.

Fig. 3. Continued. 


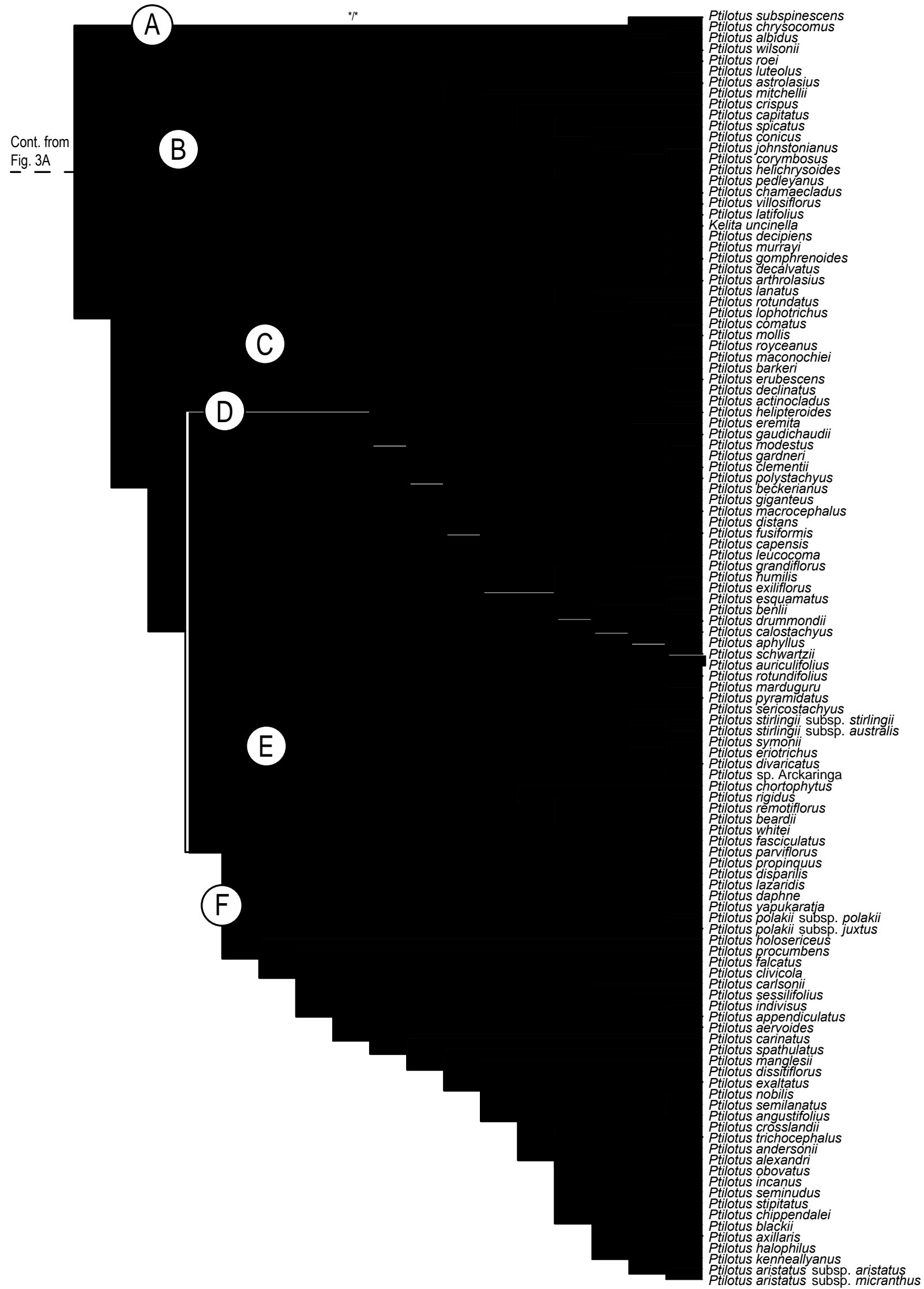

Morphology. - A number of morphological characters examined were congruent with major clades of the phylogeny and provide synapomorphies or combinations of characters that support a revised taxonomy, particularly the segregation of the traditionally circumscribed Aerva into three genera. Stigma morphology is particularly useful in this respect, as discussed below. 


\section{DISCUSSION}

Intergeneric relationships. - The present study establishes phylogenetic relationships for the major aervoid clades, allows delimitation of clades based on morphology, and demonstrates the need for revised taxonomic delimitations of some genera.

Aerva clade I forms a monophyletic group sister to Omegandra in the CDS tree (Fig. 2), with Nothosaerva clearly placed in this group in the constrained tree (Fig. 3), but without support for a clear position, probably due to the inability to sequence ITS in this species. Nothosaerva and Omegandra are morphologically distinct from all other aervoids and from each other, and we retain them as monotypic genera. Omegandra kanisii and Nothosaerva brachiata are unique within the aervoids in having four sepals (five in all other genera) and two stamens. Nothosaerva brachiata differs from $O$. kanisii in having an unlobed, capitate stigma (Fig. 4B), whereas $O$. kanisii has a minutely bilobed stigma (Fig. 4A). Omegandra kanisii and $N$. brachiata can also be distinguished from each other based on staminal cup morphology and orientation of the stamens on the cup. Nothosaerva brachiata has a staminal cup that forms a circle with two stamens on opposite sides of the ovary, and no appendages. Omegandra kanisii has a cup that is open on one side of the ovary, attached to which are two stamens alternating with three staminal cup appendages (see Leach \& al., 1993: 788, fig. 1J).

Aerva clade I was resolved as monophyletic in the present phylogeny and includes three species, the widespread Aerva javanica and two Socotran endemics, A. microphylla and A. revoluta. Aerva javanica and the Socotran species are morphologically divergent. Aerva javanica is unisexual, with female plants having a deeply bilobed, feathery stigma (Fig. 4D; males lack a style and functional stigma), unlike any other aervoid species. Aerva microphylla and A. revoluta are bisexual plants with succulent leaves (especially noticeable in the larger-leaved A. revoluta). Miller (1996) described A. microphylla and A. revoluta as having bilobed ("bifid") stigmas; however close examinations of multiple specimens of both species under SEM revealed these species to consistently possess unlobed, capitate stigmas (Fig. 4C), markedly different from the other species of Aerva and Omegandra, but similar to Ptilotus (see Fig. 4F). A single genus for these three species, while monophyletic, would be morphologically heterogeneous in this important character. For this reason, we prefer to segregate the two Socotran species from A. javanica at genus level and describe the new genus Paraerva to accommodate them. Aerva s.str. thus becomes monotypic, comprising only the morphologically divergent $A$. javanica (= A. tomentosa Forssk., the type of the genus).

Molecular evidence has indicated for some time that Aerva clade II is sister to Ptilotus (Sage \& al., 2007; Hammer \& al., 2015, 2017). All species examined in this clade have shortly bilobed stigmas (Fig. 4D,E), distinctly different from other aervoids. Ptilotus species have unlobed stigmas (Fig. 4F). Aerva clade II includes the type of Ouret Adans. (O. lanata (L.) Kuntze $=$ A. lanata). Ouret is the earliest genus name in Aerva but was rejected when Aerva was conserved (Appendix III of the ICN, https://naturalhistory2.si.edu/botany/codes-proposals/). With our segregation of Aerva into distinct genera, Ouret again becomes available as a generic name, and is the earliest available for this clade. We therefore reinstate Ouret to accommodate the eight species recognised in Aerva clade II.

Taxonomic status of Kelita. - Kelita uncinella is a prostrate annual herb known from only two populations $6 \mathrm{~km}$ apart in central-eastern Queensland, Australia. Kelita was described by Bean (2010) as being "closely allied to both Ptilotus and Omegandra" (p. 105). Bean clearly regarded that K. uncinella was most closely related to Ptilotus, but he excluded the new species from Ptilotus primarily on the basis of it having inconspicuously denticulate leaf margins, zygomorphic flowers, a conspicuous sepal midrib and uncinate sepal apices, none of which he believed occurred elsewhere in Ptilotus. He also contrasted the hard, indehiscent fruit, two fertile stamens, lack of staminal cup appendages, and axillary inflorescences of Kelita, all of which he considered to be rare in Ptilotus. These comparisons ignore much of the morphological variation within Ptilotus. Many species in Ptilotus have two fertile stamens ( $25 \mathrm{spp}$.) and many species lack staminal cup appendages ( $\sim 60 \mathrm{spp}$.). Leaf margins with small denticulations are also found in P. polystachyus (Gaudich.) F.Muell. Zygomorphic flowers occur in various Ptilotus spp. (e.g., P. declinatus, P. polystachyus and P. sericostachyus (Nees) F.Muell.), and fruit dehiscence is variable (see below). The only character that is truly unique to Kelita is the uncinate sepal apices; this is an autapomorphy within the aervoids, and hence uninformative of relationships. 

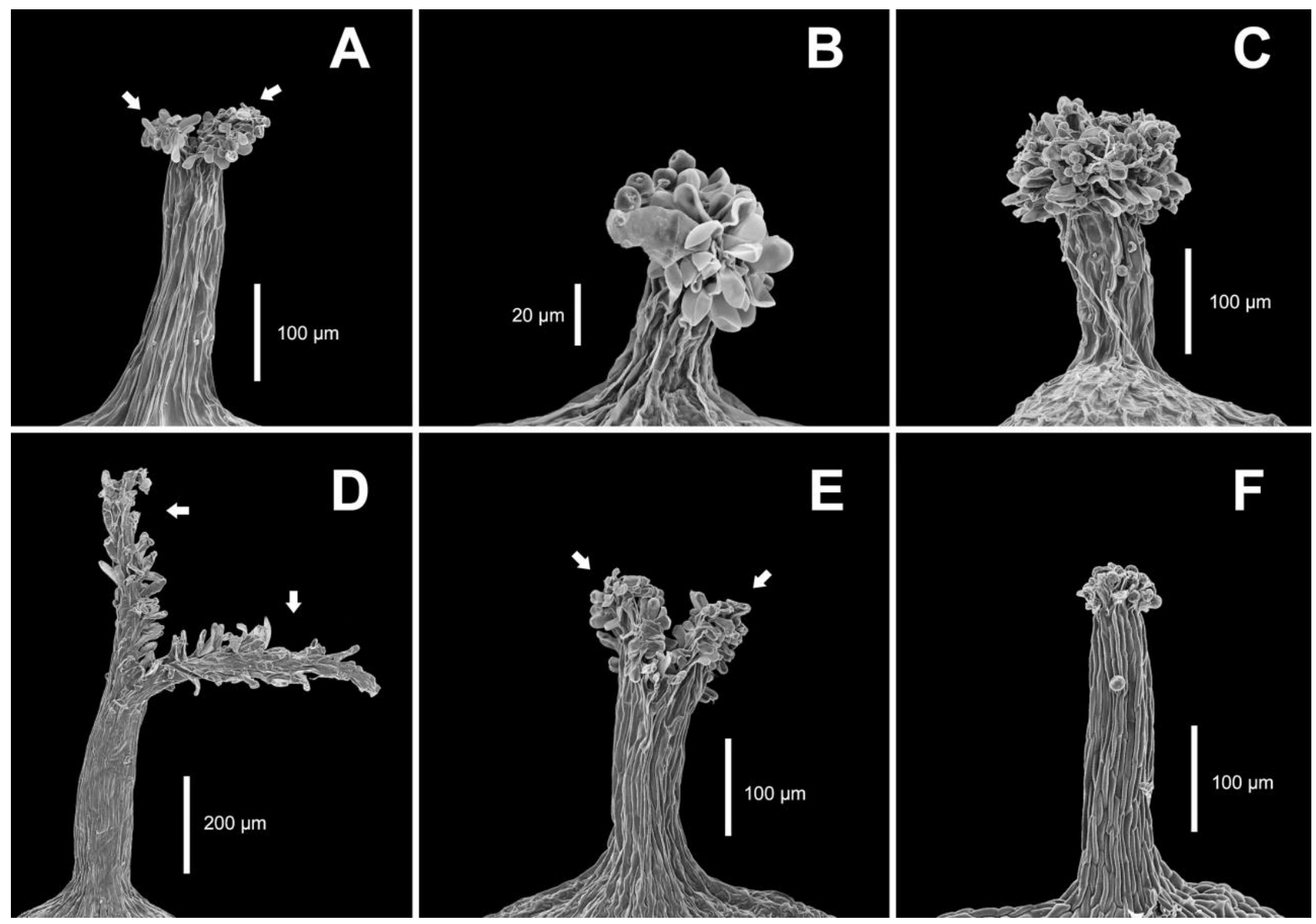

Fig. 4. SEM images of style and stigma morphology in the various clades resolved in the aervoids. A, Omegandra kanisii (BRI

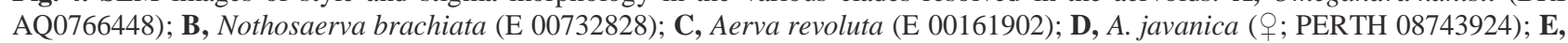
A. lanata (+; E 00732832); F, Ptilotus decipiens (PERTH 08854165). — Arrows indicate lobes on each stigma.

In both the CDS and constrained phylogenies (Figs. 2, 3), K. uncinella is nested within clade B of Ptilotus. In the latter phylogeny, $K$. uncinella is sister to P. decipiens (Benth.) C.A.Gardner, a low annual herb that occurs widely in arid Australia including Queensland. These species share axillary inflorescences, but instead of uncinate sepal apices, P. decipiens has straight-aristate bracteoles and sepals. Sepals of both species have conspicuous midribs. The uncinate sepal apices in K. uncinella and aristate apices in P. decipiens may aid in dispersal of the fruit, which remains within the persistent sepals, by animals (i.e., epizoochory; Bean, 2010). Most other species of Ptilotus have sepals that are densely hairy outside, the hairs aiding wind dispersal of the propagules (Hammer \& al., 2015, 2018b). Uncinate sepal apices, probably also to aid in epizoochory, are seen in some species in the achyranthoids (e.g., Cyathula uncinulata (Schrad.) Schinz; see Di Vincenzo \& al., 2018). Ptilotus decipiens and other related species in clade B (e.g., P. villosiflorus F.Muell. and P. chamaecladus Diels) also have a hard, indehiscent pericarp, as described for K. uncinella. Species in some other clades of Ptilotus (e.g., P. helipteroides (F.Muell.) F.Muell., P. gaudichaudii (Steud.) J.M.Black and allies in clade D) also have hardened propagules, but in these the persistent sepals harden around the enclosed fruit and pinch inward above the ovary to form a tight, indurated covering around the fruit, which has a papery pericarp (see Hammer \& Davis, 2018; Hammer \& al., 2018a). These are not homologous with the fruits of K. uncinella and its close relatives.

Kelita uncinella has a reduced number of fertile stamens (two) compared with other species in clade B (five); however, a reduction in fertile stamen number (to as low as one) is common in the more derived clades D-F (see also Hammer \& al., 2015). The position of Kelita within clade B of Ptilotus is highly supported, both with respect to morphology and the molecular data, and we thus synonymise Kelita within Ptilotus and make the new combination Ptilotus uncinellus (A.R.Bean) T.Hammer below. 


\section{TAXONOMIC TREATMENT}

The paraphyly of Aerva could be resolved by sinking all aervoid genera into a single genus, the correct name of which would be Aerva. However, such a genus would be strikingly heterogeneous, and would necessitate the loss of the largest, most recognisable and morphologically distinctive genus, Ptilotus. Given that all clades are morphologically diagnosable, we prefer to split Aerva s.l. into the three genera discussed above, viz. Aerva s.str., Ouret and Paraerva gen. nov. We believe that this generic treatment provides the best taxonomic and nomenclatural resolution of the aervoids, consistent with their phylogeny, morphology and biogeography.

The following is a list of accepted genera within the aervoids, diagnoses for each genus, lists of accepted species (excluding Ptilotus), and new combinations resulting from this study. Critical characters to differentiate the genera are provided in Table 1. The scope of this current work is to resolve the generic relationships and provide a taxonomic framework for future research. A full revisionary study within each genus is forthcoming, including a treatment of Ptilotus for the Flora of Australia (see https://profiles.ala.org.au/opus/foa).

Table 1. A comparison of characters between each of the genera recognised in the aervoids.

\begin{tabular}{|c|c|c|c|c|c|c|}
\hline Character & Omegandra & Nothosaerva & Paraerva & Aerva s.str. & Ouret & Ptilotus \\
\hline Sexuality & Hermaphrodite & Hermaphrodite & Hermaphrodite & Dioecious & $\begin{array}{l}\text { Dioecious, } \\
\text { gynodioecious or } \\
\text { hermaphrodite }\end{array}$ & $\begin{array}{l}\text { Dioecious, } \\
\text { gynodioecious or } \\
\text { hermaphrodite }\end{array}$ \\
\hline Habit & Perennial herbs & Annual herbs & Subshrubs & $\begin{array}{l}\text { Perennial } \\
\text { herbs or } \\
\text { subshrubs }\end{array}$ & Perennial herbs & $\begin{array}{l}\text { Shrubs, annual or } \\
\text { perennial herbs }\end{array}$ \\
\hline Leaf orientation & Alternate & $\begin{array}{l}\text { Alternate or } \\
\text { opposite }\end{array}$ & Alternate & Alternate & $\begin{array}{l}\text { Alternate or } \\
\text { opposite }\end{array}$ & Alternate \\
\hline $\begin{array}{l}\text { Inflorescence } \\
\text { axis }\end{array}$ & Sessile & Sessile & Pedunculate & Sessile & Sessile & $\begin{array}{l}\text { Pedunculate or } \\
\text { sessile }\end{array}$ \\
\hline $\begin{array}{l}\text { Inflorescence } \\
\text { orientation }\end{array}$ & Axillary & $\begin{array}{l}\text { Axillary or } \\
\text { terminal }\end{array}$ & Terminal & Terminal & $\begin{array}{l}\text { Axillary or } \\
\text { terminal }\end{array}$ & $\begin{array}{l}\text { Axillary or } \\
\text { terminal }\end{array}$ \\
\hline Sepal No. & 4 & 4 & 5 & 5 & 5 & 5 \\
\hline Stamen No. & 2 & 2 & 5 & 5 & 5 & $1-5$ \\
\hline Staminodes & Absent & Absent & Absent & Absent & Absent & Absent to 4 \\
\hline $\begin{array}{l}\text { Staminal cup } \\
\text { appendages }\end{array}$ & Present & Absent & Present & Present & Present & Absent or present \\
\hline Stigma lobes & Minutely bilobed & Unlobed & Unlobed & $\begin{array}{l}\text { Long- } \\
\text { bilobed }\end{array}$ & Shortly bilobed & Unlobed \\
\hline
\end{tabular}

Aerva Forssk., Fl. Aegypt.-Arab.: 170. 1775, nom. cons. - Type: A. tomentosa Forssk. (= A. javanica (Burm.f.) Juss. ex Schult.).

Diagnosis. - Erect dioecious perennial herbs or subshrubs. Leaves alternate, simple, not succulent, obovate to oblanceolate; margins entire. Inflorescences spiciform, cylindrical, sessile, terminal, solitary or in clusters, often terminally paniculate. Cymes 1 -flowered, subtended by a bract. Flowers unisexual, subtended by 2 bracteoles. Sepals 5 (3 inner and 2 outer), free. Male flowers lacking developed style and stigma; female flowers lacking developed anthers and filaments. Stamens 5, all fertile, united at their base into a short staminal cup and alternating with short, triangular staminal cup appendages. Ovary slightly laterally compressed; ovule 1; style long, straight, emergent; stigma feathery, deeply bilobed. Capsule 1-seeded, thin-walled, rupturing irregularly.

Distribution. - Occurs in W Africa, E Africa, S Asia, maritime S Asia and N Australia.

Diversity. -1 species.

Aerva javanica (Burm.f.) Juss. ex Schult. in Roemer \& Schultes, Syst. Veg. 5: 565. 1819 三Iresine javanica Burm.f., Fl. Indica: 212, t. 65, fig. 2. 1768 三Illecebrum javanicum (Burm.f.) L., Syst. Veg., ed. 13: 206. $1774 \equiv$ Achyranthes javanica (Burm.f.) Pers., Syn. Pl. 1: 259. 1805 - Lectotype (designated by Iamonico 
\& Friis in Taxon 66(5): 1210. 2017): [illustration] "Iresine javanica" in Burman, Fl. Indica: t. 65, fig. 2. 1768 (image!).

$=$ Celosia lanata L., Sp. Pl.: 205. 1753, non Aerva lanata (L.) Juss. ex Schult. 1819 - Lectotype (designated by Townsend in Polhill, Fl. Trop. East Afr., Amaranth.: 84. 1985): Sri Lanka. Herb. Hermann Vol. 4: 52 (BM barcode BM000628252 [image!]).

= Aerva tomentosa Forssk., Fl. Aegypt.-Arab.: 170. 1775 - Lectotype (designated by Townsend in Polhill, Fl. Trop. East Afr., Amaranth.: 84. 1985): Egypt. Cairo, Forsskål 918 (C barcode C10001593).

$=$ Iresine persica Burm.f., Fl. Indica: 212, t. 65, fig. 2. $1768 \equiv$ Ouret persica (Burm.f.) Kuntze, Revis. Gen. Pl. 2: 544.1891 ('Uretia') $\equiv$ Aerva persica (Burm.f.) Merr. in Philipp. J. Sci. 19(3): 348. 1921 - Holotype (vide Townsend in Polhill, Fl. Trop. East Afr., Amaranth.: 84. 1985): Iran. Herb. Burman (G).

Notes. - Schultes ascribed this species to Jussieu (1803), but A.L. de Jussieu only stated that he believed Illecebrum javanicum (Burm.f.) L. to be in Aerva, but did not specifically assign the genus name with the specific epithet, as required in Art. 35.2 in the ICN (Turland \& al., 2018). Iamonico \& Friis (2017) includes a discussion on the nomenclature and lectotypification of Aerva tomentosa and Iresine javanica Burm.f.

Nothosaerva Wight, Icon. P1. Ind. Orient. 6: 1. 1853 三 Pseudanthus Wight, Icon. Pl. Ind. Orient. 5(2): 3. 1852, nom. illeg., non Sieber ex A.Spreng. - Type: N. brachiata (L.) Wight.

Diagnosis. - Erect annual herbs. Leaves simple, opposite or alternate, not succulent, narrowly ovate to lanceolate; margins entire. Inflorescences spiciform, cylindrical, terminal or axillary, clustered. Cymes 1flowered, subtended by a bract. Flowers bisexual, subtended by 2 bracteoles. Sepals 4 ( 2 inner and 2 outer), free. Stamens 2, both fertile, united at their base into a short staminal cup, opposite the two outer sepals; staminal cup appendages absent. Ovary laterally compressed; ovule 1; style very short, straight; stigma unlobed, capitate. Capsule 1-seeded, thin-walled, rupturing irregularly.

Distribution. - Occurs throughout Sub-Saharan Africa, the Maldives, Mauritius, and southern parts of Asia (from Arabia to Borneo).

Diversity. -1 species.

Nothosaerva brachiata (L.) Wight, Icon. P1. Ind. Orient. 6: 1. 1853 =Achyranthes brachiata L., Mant. Pl.: 50. $1767 \equiv$ Illecebrum brachiatum (L.) L., Mant. Pl.: 213. $1771 \equiv$ Aerva brachiata (L.) Mart., Beitr. Amarantac.: 83. $1825 \equiv$ Pseudanthus brachiatus (L.) Wight, Icon. Pl. Ind. Orient. 5(2): 3. 1852 - Lectotype (designated by Townsend in Nasir \& Ali, Fl. W. Pakistan 71: 32. 1974): Herb. Linn. No. 290.1 (LINN [image!]).

= Illecebrum bengalense L., Mant. Pl.: 213. 1771 EAchyranthes bengalensis (L.) Lam., Encycl. 1: 549. 1785 - Lectotype (designated by Iamonico \& Friis in Taxon 66(5): 1209. 2017): Herb. Linn. No. 290.18 (LINN [image!]).

Omegandra G.J.Leach \& C.C.Towns. in Kew Bull. 48(4): 787. 1993 - Type: O. kanisii G.J.Leach \& C.C.Towns.

Diagnosis. - Prostrate to decumbent bisexual perennial herbs. Leaves simple, alternate, elliptic to lanceolate; margins entire. Inflorescences spiciform, cylindrical, axillary, solitary or in clusters. Cymes 1flowered, subtended by a bract. Flowers bisexual, subtended by 2 bracteoles. Sepals 4 ( 2 inner and 2 outer), free. Stamens 2, both fertile, united at their base into a short staminal cup that is open on the abaxial side with 3 staminal cup appendages alternating with the stamens. Ovary slightly laterally compressed; ovule 1; style straight; stigma minutely bilobed. Capsule 1-seeded, thin-walled, rupturing irregularly.

Distribution. - Occurs in the northern parts of Queensland and the Northern Territory, Australia.

Diversity. -1 species.

Omegandra kanisii G.J. Leach \& C.C.Towns. in Kew Bull. 48(4): 787. 1993 - Holotype: Australia. Northern Territory: South Alligator Floodplain, Kakadu National Park, 7 Aug 1990, I. Cowie 1334 (DNA barcode DNA-D0053029 [image!]; isotypes: BRI barcode BRI-AQ0511960 [image!], CANB barcode CANB00402446 [image!], K barcode K000587476 [image!]).

Ouret Adans., Fam. Pl. 2: 268, 586. 1763 ('Uretia' Kuntze, Revis. Gen. Pl. 2: 544. 1891, orth. var.) - Type (designated by Rickett \& Stafleu in Taxon 8: 268. 1959): O. lanata (L.) Kuntze.

Diagnosis. - Decumbent to erect bisexual or dioecious annual or perennial herbs. Leaves simple, alternate or opposite, not succulent, ovate, obovate or elliptic; margins entire, sometimes revolute. Inflorescences spiciform, cylindrical, sessile, terminal or axillary, solitary or in clusters. Cymes 1-flowered, subtended by a 
bract. Flowers unisexual or bisexual, subtended by 2 bracteoles. Sepals 5 ( 3 inner and 2 outer), free. Male flowers (when unisexual) lacking developed stigma; female flowers lacking developed anthers and filaments. Stamens 5, all fertile, united at their base into a short staminal cup and alternating with short to long, broadly to narrowly triangular staminal cup appendages. Ovary slightly laterally compressed; ovule 1; style straight; stigma shortly bilobed. Capsule 1-seeded, thin-walled, rupturing irregularly.

Distribution. - Occurs in tropical W Africa, S Africa, E Africa, Madagascar, Mauritius and nearby islands, and southern Asia (i.e., including Arabia, India, Indochina and maritime S Asia).

Diversity. -8 species.

Notes. - Adanson (1763: 586) described Ouret based on Achyranthes lanata L. and Celosia lanata L. Adanson's name was given a latinised form, "Uretia", by Rafinesque (1837: 40), who cited Achyranthes alternifolia L. (三Uretia alternifolia (L.) Raf.) as type. Achyranthes alternifolia is now an accepted synonym of Digera muricata (L.) Mart. subsp. muricata by way of D. alternifolia (L.) Aschers. (see Miller, 1996: 293). Kuntze (1891: 544) combined several Aerva species under "Uretia" (again, a latinised orthographic variant of Ouret) and cited Achyranthes lanata and Celosia lanata, presumably unaware of Rafinesque's previous treatment. Hiern (1900: 883) included three of Kuntze's species under Ouret, giving Kuntze's "Uretia" names as synonyms.

The conservation of the name Aerva over Ouret was proposed by Ascherson (1892: 333; Ouret, as "Oureti") and Harms (1904: 17) and later ratified in 1905 by the II International Botanical Congress, Vienna (Briquet, 1906: 241). Rickett \& Stafleu (1959: 268) later specified Achyranthes lanata as the type for Ouret. As the name Ouret is validly published, it remains the earliest available for our segregate genus. Species within our concept of Ouret that Kuntze (1891) formally included in "Uretia" were O. lanata (L.) Kuntze, O. sanguinolenta (L.) Kuntze, O. glabrata (Hook.f.) Kuntze, O. congesta (Balf.f. ex Baker) Kuntze and O. leucura (Moq.) Kuntze.

Thiv \& al. (2006) included multiple accessions of $O$. lanata in their phylogenetic analysis of Aerva s.l. and found that some of these grouped with specimens of $O$. sanguinolenta while others grouped with $O$. leucura. A thorough investigation of taxonomic boundaries among these species is warranted, which is outside the scope of the current study. For this reason, we have chosen not to designate lectotypes for the species of Ouret at this time.

Ouret congesta (Balf.f. ex Baker) Kuntze, Revis. Gen. Pl. 2: 544.1891 ('Uretia') $\equiv$ Aerva congesta Balf.f. ex Baker, Fl. Mauritius: 267. 1877 - Syntypes: Mauritius. "Rodrigues, only on coral, near the shore", 1874, Balfour s.n. (K barcode K000243711 [image!], M barcode M-0088599 [image!]).

Ouret coriacea (Schinz) T.Hammer, comb. nov. $\equiv$ Aerva coriacea Schinz in Vierteljahrsschr. Naturf. Ges. Zürich 76: 141. 1931 - Syntypes: Madagascar. "Prov. Tuléar, collines calcaires du Fiherena", F. Geay 5308 (P barcode P04942221 [image!]); F. Geay 5308 bis (P barcode P00347809 [image!]).

Ouret glabrata (Hook.f.) Kuntze, Revis. Gen. Pl. 2: 544.1891 ('Uretia') 三 Aerva glabrata Hook.f., Fl. Brit. India 4(12): 728. 1885 - Syntype: Myanmar. Griffith 4185 (K barcode K000848082 [image!]).

Ouret humbertii (Cavaco) T.Hammer, comb. nov. $\equiv$ Aerva humbertii Cavaco in Bull. Soc. Bot. France 99: 253. 1952 - Syntypes: Madagascar. "Vallée de la Manambolo", H. Humbert 12848 (P barcodes P00346821 [image!] \& P00346822 [image!]).

Ouret lanata (L.) Kuntze, Revis. Gen. P1. 2: 544.1891 ('Uretia') $\equiv$ Achyranthes lanata L., Sp. Pl.: 204. 1753 $\equiv$ Illecebrum lanatum (L.) L., Mant. Pl.: 344. 1771 =Aerva lanata (L.) Juss. ex Schult. in Roemer \& Schultes, Syst. Veg. 5: 564. 1819 - Lectotype (designated by Iamonico in Taxon 63(2): 407. 2014): [illustration] "AMARANTUS spicatus Zeylanicus, foliis obtusis, \&c" in Burman, Thes. Zeylan.: t. 26, fig. 1.1736 ("1737") (image!).

= Achyranthes villosa Forssk., Fl. Aegypt.-Arab.: 48. 1775 - Syntypes: Yemen. Al Hadiyah, Mar 1763, P. Forsskål 203 (C barcode C10001571 [image!], LD barcode LD1756837 [image!]).

= Aerva elegans Moq. in Candolle, Prodr. 13(2): 303. 1849 - Syntypes: Yemen. "Arabie [Arabia] Taifa Mont Moamara", 1838, P.E. Botta s.n. (P barcodes P00609991 [image!] \& P00609992 [image!]).

Ouret leucura (Moq.) Kuntze, Revis. Gen. Pl. 2: 544.1891 ('Uretia') 三Aerva leucura Moq. in Candolle, Prodr. 13(2): 302. 1849 三Illecebrum leucurum Hort. Berol. ex Moq. in Candolle, Prodr. 13(2): 302. 1849 $\equiv$ Aerva burchellii Moq., Prodr. 13(2): 302. 1849 - Syntype: South Africa. Griqualand West: "at 
Griquatown [Griekwastad] in Leeuwenkuil Valley", 14 Dec 1811, W.J. Burchell 1892 (K barcode K000243712 [image!]).

= Aerva ambigua Moq. in Candolle, Prodr. 13(2): 302. 1849 - Syntype: South Africa. Transvaal: "In Africa australi ad Vaal River", Burke s.n. (K barcode K000243714 [image!]).

Ouret sanguinolenta (L.) Kuntze, Revis. Gen. Pl. 2: 544. 1891 ('Uretia') $\equiv$ Achyranthes sanguinolenta L., Sp. Pl., ed. 2: 294. $1762 \equiv$ Illecebrum sanguinolentum (L.) L., Mant. Pl.: $344.1771 \equiv$ Aerva sanguinolenta (L.) Blume, Bijdr. Fl. Ned. Ind.: 547. 1826 - Lectotype (designated by Townsend in Nasir \& Ali, Fl. W. Pakistan 71: 30. 1974): Herb. Linn. No. 290.3 (LINN [image!]).

$=$ Achyranthes scandens Roxb., Fl. Ind. 2: 503. $1824 \equiv$ Aerva scandens (Roxb.) Wight, Icon. Pl. Ind. Orient. 2: t. $724.1843 \equiv$ Aerva scandens (Roxb.) Moq., Prodr. 13(2): 302. 1849, nom. superfl. $\equiv$ Aerva scandens (Roxb.) Wall. ex Hook.f., Fl. Brit. India 4(12): 727-728. 1885, nom. superfl. $\equiv$ Ouret scandens (Roxb.) Hiern, Cat. Afr. Pl. 1: 893. 1900 - Syntype: s. loc., N. Wallich 6911 (BR barcode BR00000006950354 [image!]).

= Aerva timorensis Moq. in Candolle, Prodr. 13(2): 301. 1849 - Syntype: Indonesia. Timor: "Ile de Timor", J. Decaisne s.n. (P barcode P00610525 [image!]).

= Aerva velutina Moq. in Candolle, Prodr. 13(2): 301. 1849 - Syntypes: Philippines. "Is of Panay", Mar 1837, H. Cuming 1635 (K barcode K000848079 image!); "Indes orientales", N. Wallich 833 (P barcodes P00609997 [image!] \& P00609998 [image!]).

Ouret triangularifolia (Cavaco) T.Hammer, comb. nov. $\equiv$ Aerva triangularifolia Cavaco in Bull. Soc. Bot. France 99: 253. 1953 - Syntypes: Madagascar. "Environs de Tuléar", Aug 1919, H. Perrier de la Bâthie 12790 (P barcodes P00347804 [image!] \& P00347805 [image!]).

Paraerva T.Hammer, gen. nov. - Type: P. revoluta (Balf.f.) T.Hammer (三 Aerva revoluta Balf.f.).

Diagnosis. - Erect bisexual subshrubs. Leaves alternate, succulent or semi-succulent, obovate, simple, discolorous; margins entire, sometimes revolute. Inflorescences spiciform, cylindrical to ovoid, sessile or pedunculate, terminal, solitary or in clusters. Cymes 1-flowered, subtended by a bract. Flowers bisexual, subtended by 2 bracteoles. Sepals 5 ( 3 inner and 2 outer), free. Stamens 5 , all fertile, united at their base into a short staminal cup and alternating with short, triangular staminal cup appendages. Ovary slightly laterally compressed; ovule 1; style short, straight; stigma unlobed, capitate (Fig. 4C). Capsule 1-seeded, thin-walled, rupturing irregularly.

Distribution. - Endemic to the island of Socotra.

Diversity. -2 species.

Etymology. - From the Greek para- ("beside" or "next to") and the genus name Aerva, referring to the phylogenetic placement of the new genus with respect to Aerva.

Paraerva microphylla (Moq.) T.Hammer, comb. nov. 三 Aerva microphylla Moq. in Candolle, Prodr. 13(2): 301. 1849 三 Ouret microphylla (Moq.) Kuntze, Revis. Gen. Pl. 2: 544.1891 ('Uretia') - Lectotype (designated here): Yemen. Socotra: Nimmo s.n. (K barcode K000243701 [image!]).

Paraerva revoluta (Balf.f.) T.Hammer, comb. nov. $\equiv$ Aerva revoluta Balf.f., Proc. Roy. Soc. Edinburgh 12: 92. $1884 \equiv$ Ouret revoluta (Balf.f.) Kuntze, Revis. Gen. Pl. 2: 544.1891 ('Uretia') - Lectotype (designated here): Yemen. Socotra: "in montibus Haghier", Dec 1883, B.C.S. 478 (K barcode K000243697 [image!]).

Notes. - Of the two specimens cited in the protologue by Balfour (1884), we nominate B.C.S. 478 (K000243697) as the lectotype. It consists of four flowering woody stems with leaves and matches the protologue. The specimen Schweinfurth 558 (M-0107324) consists of a single plant with several flowering stems attached to a woody base.

Ptilotus R.Br., Prodr.: 415. 1810 - Type (designated by Iamonico in Phytotaxa 350(2): 151. 2018): P. corymbosus R.Br.

= Trichinium R.Br., Prodr.: 414. 1810 - Type: none designated.

= Goniotriche Turcz. in Bull. Soc. Imp. Naturalistes Moscou 22(3): 371849 - Type: G. tomentosa Turcz. (= Ptilotus obovatus (Gaudich.) F.Muell.).

= Hemisteirus F.Muell. in Linnaea 25: 434. 1853 - Type: H. psilotrichodes F.Muell. (三 Ptilotus modestus T.Hammer). 
= Dipteranthemum F.Muell. ex Oliv. in Hooker's Icon. P1. 16: t. 1541. 1886 - Type: D. crosslandii F.Muell ex Oliv. (三 Ptilotus crosslandii (F.Muell. ex Oliv.) Benl).

= Kelita A.R.Bean in Muelleria 28(2): 105. 2010, syn. nov. - Type: K. uncinella A.R.Bean (三Ptilotus uncinellus (A.R.Bean) T.Hammer).

- "Arthrotrichum" F.Muell. in Trans. Bot. Soc. Edinburgh 7: 500. 1863, not validly published (Art. 36.1).

Diagnosis. - Erect, decumbent or prostrate bisexual, rarely dioecious (1 sp.) or gynodioecious shrubs or annual or perennial herbs. Leaves simple, alternate or rarely subopposite, not or rarely succulent, linear to orbicular, concolorous or rarely discolorous; margins entire or rarely denticulate, sometimes revolute or undulate. Inflorescences spiciform, ovoid to cylindrical, sessile or pedunculate, terminal or axillary, solitary or in clusters. Cymes 1-flowered, subtended by a bract. Flowers bisexual or unisexual, subtended by 2 bracteoles, often showy and coloured. Sepals 5 (3 inner and 2 outer), free. Stamens 5, all fertile or 1-4 fertile and the others reduced to inconspicuous or showy staminodes, united at their base into a staminal cup; staminal cup appendages absent or present and alternating with stamens. Ovary slightly laterally compressed; ovule 1; style centrally or eccentrically fixed on the ovary, short or long, straight, curved or sigmoid; stigma unlobed, capitate. Capsule 1-seeded, thin-walled and rupturing irregularly, rarely indurate and indehiscent.

Distribution. - All species are native to continental Australia; some species also occur on adjacent islands (e.g., P. capensis (Benl) A.R.Bean extending to the Torres Strait Islands) and Tasmania (i.e., P. spathulatus (R.Br.) Poir.), with only P. conicus extending outside of Australia to the Lesser Sunda Islands (e.g., Timor) and Aru Islands (i.e., Trangan).

Diversity. - Approximately 120 species.

Notes. - A full list and an electronic identification key to the species of Ptilotus is maintained and updated regularly on the online platform KeyBase (available at http://keybase.rbg.vic.gov.au/keys/show/6609). See Hammer \& al. (2015) for a discussion on the taxonomic history of Ptilotus, Trichinium and Dipteranthemum F.Muell. ex Oliv. and Hammer \& al. (2018a) for discussion of Hemisteirus F.Muell. Ptilotus corymbosus R.Br., one of the two original species of the genus, was recently designated as the type of the genus name by Iamonico (2018).

Dipteranthemum is sometimes attributed to F.Muell. (in S. Sci. Rec. 3: 281. 1883 or 1884). However, it appears that the relevant portion of Volume 3 of the Southern Science Record was never published. Although Mueller distributed "extra-prints" of his own paper to a small number of correspondents this is not regarded as meeting the requirements of effective publication under ICN Art. 29. The names were later validly published by Oliver as a descriptio generico-specifica under ICN Art. 38.5 (Turland \& al., 2018).

Ptilotus uncinellus (A.R.Bean) T.Hammer, comb. nov. $\equiv$ Kelita uncinella A.R.Bean in Muelleria 28(2): 106109, fig. 1. 2010 - Holotype: Australia. Queensland: WNW of Glenden [precise locality withheld for conservation reasons], 8 Jun 2009, A.R. Bean 29009 (BRI barcode BRI-AQ0821100 [image!]; isotypes: CANB barcode CANB00725761 [image!], K barcode K000913312 [image!], L barcode L.3709750 [image!], MEL barcode MEL 2358710 [image!], NY barcode 01842825 [image!]).

\section{AUTHOR CONTRIBUTION STATEMENT}

TAH devised the project with supervision by KRT and IDS. PGN and IDS provided genome sequences and funding for analysis. TAH gathered data, performed the analyses, and interpreted the results. XZ and CCdF aided in gathering and analysis of the genomic data. TAH wrote all sections of the manuscript and produced the figures. $\mathrm{XZ}$ and $\mathrm{CCdF}$ wrote parts of the methods section. The taxonomy section was written by TAH and KRT. The draft manuscript was revised by PGN, IDS and KRT.

\section{ACKNOWLEDGEMENTS}

The directors and staff of the cited herbaria provided access to their collections, and we thank them for loaning specimens. The following individuals provided substantial assistance: Robert Davis (Perth, Australia), Terena Lally (Canberra, Australia), Peter Jobson (Alice Springs, Australia), Steven Dillon (Perth, Australia), Alan Forrest (Edinburgh, U.K.), Laco Mucina (Perth, Australia), Margaret Byrne (Perth, Australia), Bronwyn MacDonald (Perth, Australia), Anna Monro (Canberra, Australia) and Nicholas Turland (Berlin, Germany). We also thank Alena Vydrova and Vit Grulich (Brno, Czech Republic) for permission to use their photograph. TAH acknowledges the support of a Forrest Research Foundation Ph.D. scholarship and University 
Postgraduate Award (UWA). XZ, CCdF and IS are supported by the Australian Research Council (grants CE140100008 and FL140100179). PGN was supported partly by the Australian Government through the Australian Research Council Industrial Transformation Training Centre for Mine Site Restoration (project number ICI150100041). The views expressed herein are those of the authors and are not necessarily those of the Australian Government or Australian Research Council.

\section{LITERATURE CITED}

Ascherson, H. 1892. Vorläufiger Bericht über die von Berliner Botaniker unternommenen Schritte zur Ergänzung der "Lois de la nomenclature botanique". Ber. Deutsch. Bot. Ges. 10: 327-359.

Adanson, M. 1763. Familles des plantes. Paris: chez Vincent. https://doi.org/10.5962/bhl.title.271

Balfour, I.B. 1884. Diagnoses plantarum novarum Phanerogamarum Socotrensium, etc.; [...] pars tertia. Proc. Roy. Soc. Edinburgh 12: 76-98.

Bankevich, A., Nurk, S., Antipov, D., Gurevich, A.A., Dvorkin, M., Kulikov, A.S., Lesin, V.M., Nikolenko, S.I., Pham, S., Prjibelski, A.D., Pyshkin, A.V., Sirotkin, A.V., Vyahhi, N., Tesler, G., Alekseyev, M.A. \& Pevzner, P.A. 2012. SPAdes: A new genome assembly algorithm and its applications to single-cell sequencing. J. Computat. Biol. 19: 455-477. https://doi.org/10.1089/cmb.2012.0021

Bapst, D.W. 2012. paleotree: An R package for paleontological and phylogenetic analyses of evolution. Meth. Ecol. Evol. 3: 803-807. https://doi.org/10.1111/j.2041-210X.2012.00223.x

Bean, A.R. 2010. Kelita (Amaranthaceae), a new genus from Queensland, Australia. Muelleria 28(2): 105109.

Bentham, G. \& Hooker, J.D. 1880. Genera plantarum, vol. 3(1). Londini [London]: venit apud L. Reeve. https://doi.org/10.5962/bhl.title.747

Borsch, T., Flores-Olvera, H., Zumaya, S. \& Müller, K. 2018. Pollen characters and DNA sequence data converge on a monophyletic genus Iresine (Amaranthaceae, Caryophyllales) and help to elucidate its species diversity. Taxon 67: 944-976. https://doi.org/10.12705/675.7

Briquet, J. 1906. Règles internationales de la Nomenclature botanique. Pp. 165-261 in: Wettstein, R. v., Wiesner, J. \& Zahlbruckner, A. (eds.), Verhandlungen des Internationalen botanischen Kongresses in Wien $1905=$ Actes du Congrès International de Botanique tenu à Vienne (Autriche) 1905. Jena: G. Fischer. https://doi.org/10.5962/bhl.title.11012

Bushnell, B., Rood, J. \& Singer, E. 2017. BBMerge - Accurate paired shotgun read merging via overlap. PLoS ONE 12(10): e0185056. https://doi.org/10.1371/journal.pone.0185056

Darriba, D., Taboada, G.L., Doallo, R. \& Posada, D. 2012. jModelTest 2: More models, new heuristics and parallel computing. Nature, Meth. 9: 772. https://doi.org/10.1038/nmeth.2109

Davis, R.W. 2012. Ptilotus christineae is synonymous with the previously presumed extinct taxon P. pyramidatus. Nuytsia 22(5): 335 .

Dierckxsens, N., Mardulyn, P. \& Smits, G. 2016. NOVOPlasty: De novo assembly of organelle genomes from whole genome data. Nucl. Acids Res. 45(4): e18. https://doi.org/10.1093/nar/gkw955

Di Vincenzo, V., Gruenstaeudl, M., Nauheimer, L., Wondafrash, M., Kamau, P., Demissew, S. \& Borsch, T. 2018. Evolutionary diversification of the African achyranthoid clade (Amaranthaceae) in the context of sterile flower evolution and epizoochory. Ann. Bot. (Oxford) 122: 69-85. https://doi.org/10.1093/aob/mcy055

Endlicher, S. 1837 (“1836-1840”). Genera plantarum secundum ordines naturales disposita. Vindobonae [Vienna]: apud Fr. Beck. https://doi.org/10.5962/bhl.title.728

Gardner, A.G., Sessa, E.B., Michener, P., Johnson, E., Shepherd, K.A., Howarth, D.G. \& Jabaily, R.S. 2016. Utilizing next-generation sequencing to resolve the backbone of the Core Goodeniaceae and inform future taxonomic and floral form studies. Molec. Phylogen. Evol. 94: 605-617. https://doi.org/10.1016/j.ympev.2015.10.003

Hammer, T.A. \& Davis, R.W. 2018. Ptilotus actinocladus (Amaranthaceae), a new and rare species from the Gascoyne Bioregion, Western Australia. Nuytsia 29: 145-149.

Hammer, T., Davis, R. \& Thiele, K. 2015. A molecular framework phylogeny for Ptilotus (Amaranthaceae): Evidence for the rapid diversification of an arid Australian genus. Taxon 64(2): 272-285. http://doi.org/10.12705/642.6

Hammer, T.A., Davis, R.W. \& Thiele, K.R. 2017. Wadithamnus, a new monotypic genus in Amaranthaceae. Phytotaxa 295(2): 173-184. https://doi.org/10.11646/phytotaxa.295.2.5 
Hammer, T.A., Davis, R.W. \& Thiele, K.R. 2018a. The showy and the shy: Reinstatement of two species from Ptilotus gaudichaudii (Amaranthaceae). Austral. Syst. Bot. 31(1): 1-7. https://doi.org/10.1071/SB17026

Hammer, T.A., Macintyre, P.D., Nge, F.J., Davis, R.W., Mucina, L. \& Thiele, K.R. 2018b. The noble and the exalted: A multidisciplinary approach to resolving a taxonomic controversy within Ptilotus (Amaranthaceae). Austral. Syst. Bot. 31(3): 262-280. https://doi.org/10.1071/SB17062

Harms, H. 1904. Vorschlag zur Ergänzung der "Lois de la nomenclature botanique de 1867", dem in Wien 1905 tagenden Nomenclatur-Kongreß zur Annahme empfohlen. Notizbl. Königl. Bot. Gart. Berlin 4: 137. https://doi.org/10.2307/3993987

Hernández-Ledesma, P., Berendsohn, W.G., Borsch, T., Mering, S. von, Akhani, H., Arias, S., Castañeda-Noa, I., Eggli, U., Eriksson, R., Flores-Olvera, H., Fuentes-Bazán, S., Kadereit, G., Klak, C., Korotkova, N., Nyffeler, R., Ocampo, G., Ochoterena, H., Oxelman, B., Rabeler, R.K., Sanchez, A., Schlumpberger, B.O. \& Uotila, P. 2015. A taxonomic backbone for the global synthesis of species diversity in the angiosperm order Caryophyllales. Willdenowia 45(3): 281-383. https://doi.org/10.3372/wi.45.45301

Hiern, W.F. 1900. Catalogue of the African plants, vol. 1(4). London: printed by order of the Trustees. https://doi.org/10.5962/bhl.title.10876

Iamonico, D. 2018. Generic typifications in Amaranthaceae s.str. Phytotaxa 350(2): 147-154. https://doi.org/10.11646/phytotaxa.350.2.3

Iamonico, D. \& Friis, I. 2017. The lectotypification of two names referred by Linnaeus to the genus Illecebrum (Caryophyllales): Illecebrum benghalense and Iresine javanica, with comments on Aerva tomentosa. Taxon 66(5): 1208-1212. https://doi.org/10.12705/665.14

Jussieu, A.L. de 1803. Observations sur la famille des plantes amarantacées. Ann. Mus. Natl. Hist. Nat. 2: 131-135.

Kadereit, G., Borsch, T., Weising, K. \& Freitag, H. 2003. Phylogeny of Amaranthaceae and Chenopodiaceae and the evolution of $\mathrm{C}_{4}$ photosynthesis. Int. J. Pl. Sci. 164(6): 959-986. https://doi.org/10.1086/378649

Katoh, K. \& Standley, D.M. 2013. MAFFT multiple sequence alignment software version 7: Improvements in performance and usability. Molec. Biol. Evol. 30(4): 772-780. https://doi.org/10.1093/molbev/mst010

Kearse, M., Moir, R., Wilson, A., Stones-Havas, S., Cheung, M., Sturrock, S., Buxton, S., Cooper, A., Markowitz, S., Duran, C., Thierer, T., Ashton, B., Mentjies, P. \& Drummond, A. 2012. Geneious Basic: An integrated and extendable desktop software platform for the organization and analysis of sequence data. Bioinformatics 28(12): 1647-1649. https://doi.org/10.1093/bioinformatics/bts199

Kuntze, O. 1891. Revisio generum plantarum, vol. 2. Leipzig: Arthur Felix. https://doi.org/10.5962/bhl.title.327

Kurtz, S., Phillippy, A., Delcher, A.L., Smoot, M., Shumway, M., Antonescu, C. \& Salzberg, S.L. 2004. Versatile and open software for comparing large genomes. Genome Bio. 5: R12. https://doi.org/10.1186/gb-2004-5-2-r12

Lally, T.R. 2008. Resolution of the Ptilotus parvifolius complex (Amaranthaceae). J. Adelaide Bot. Gard. 22: $37-46$.

Lanfear, R., Frandsen, P.B., Wright, A.M., Senfeld, T. \& Calcott, B. 2016. PartitionFinder 2: New methods for selecting partitioned models of evolution for molecular and morphological phylogenetic analyses. Molec. Biol. Evol. 34: 772-773. https://doi.org/10.1093/molbev/msw260

Leach, G.J., Townsend, C.C. \& Harley M.M. 1993. Omegandra, a new genus of Amaranthaceae from Australia. Kew Bull. 48(4): 787-793. https://doi.org/10.2307/4118858

Léveillé-Bourret, E., Starr, J.R., Ford, B.A., Lemmon, E.M. \& Lemmon, A.R. 2018. Resolving rapid radiations within angiosperm families using anchored phylogenomics. Syst. Biol. 67(1): 94-112. https://doi.org/10.1093/sysbio/syx050

Li, H. 2013. Aligning sequence reads, clone sequences and assembly contigs with BWA-MEM. arXiv: 1303.3997 [q-bio.GN]. https://arxiv.org/abs/1303.3997

Ma, P., Zhang, Y., Zeng, C., Guo, Z. \& Li, D. 2014. Chloroplast phylogenomic analyses resolve deep-level relationships of an intractable bamboo tribe Arundinarieae (Poaceae). Syst. Biol. 63(6): 933-950. https://doi.org/10.1093/sysbio/syu054

Martin, M. 2011. Cutadapt removes adapter sequences from high-throughput sequencing reads. EMBnet.journal 17(1): 10-12. https://doi.org/10.14806/ej.17.1.200

Miller, A.G. 1996. Amaranthaceae. Pp. 295-299 in: Miller, A.G. \& Cope, T.A. (eds.), Flora of Arabian Peninsula and Socotra, vol. 1. Edinburgh: Edinburgh University Press. 
Miller, M.A., Pfeiffer, W. \& Schwartz, T. 2010. Creating the CIPRES Science Gateway for inference of large phylogenetic trees. Pp. 45-52 in: Proceedings of the Gateway Computing Environments Workshop $(G C E)$, New Orleans, Louisiana, 14 Nov 2010. Piscataway: IEEE. https://doi.org/10.1109/GCE.2010.5676129

Moquin-Tandon, A. 1849. Amaranthaceae. Pp. 231-241 in: Candolle, A. de (ed.), Prodromus systematis naturalis regni vegetabilis, vol. 13(2). Parisiis [Paris]: sumtibus Victoris Masson. https://doi.org/10.5962/bhl.title.286

Motley, T.J., Wurdack, K.J. \& Delprete, P.G. 2005. Molecular systematics of the Catesbaeeae-Chiococceae complex (Rubiaceae): Flower and fruit evolution and biogeographic implications. Amer. J. Bot. 92: 316329. https://doi.org/10.3732/ajb.92.2.316

Müller, K. \& Borsch, T. 2005. Phylogenetics of Amaranthaceae based on matK/trnK sequence data: Evidence from parsimony, likelihood, and Bayesian analyses. Ann. Missouri Bot. Gard. 92: 66-102.

Rafinesque, C.S. 1837. Flora telluriana, vol. 3. Philadelphia: printed for the author. https://doi.org/10.5962/bhl.title.7751

Rambaut, A. \& Drummond, A.J. 2007. Tracer, version 1.6. http://beast.bio.ed.ac.uk/Tracer

Rickett, H.W. \& Stafleu, F.A. 1959. Nomina generica conservanda et rejicienda spermatophytorum II [Continued]. Taxon 8(8): 256-274. https://doi.org/10.2307/1216847

Ronquist, F., Teslenko, M., Van der Mark, P., Ayres, D.L., Darling, A., Höhna, S., Larget, B., Liu, L., Suchard, M.A. \& Huelsenbeck, J.P. 2012. MrBayes 3.2: Efficient Bayesian phylogenetic inference and model choice across a large model space. Syst. Biol. 61: 539-542. https://doi.org/10.1093/sysbio/sys029

Ronse De Craene, L.P. 2013. Reevaluation of the perianth and androecium in Caryophyllales: Implications for flower evolution. Pl. Syst. Evol. 299: 1599-1636. https://doi.org/10.1007/s00606-013-0910-y

Sage, R.F., Sage, T.L., Pearcy, R.W. \& Borsch, T. 2007. The taxonomic distribution of $\mathrm{C}_{4}$ photosynthesis in Amaranthaceae sensu stricto. Amer. J. Bot. 94: 1992-2003. https://doi.org/10.3732/ajb.94.12.1992

Sang, T., Crawford, D.J. \& Stuessy, T.F. 1997. Chloroplast DNA phylogeny, reticulate evolution, and biogeography of Paeonia (Paeoniaceae). Amer. J. Bot. 84: 1120-1136. https://doi.org/10.2307/2446155

Schinz, H. 1893. Amaranthaceae. Pp. 91-118 in: Engler, A. \& Prantl, K. (eds.), Die natürlichen Pflanzenfamilien, III(1a). Leipzig: Engelmann. https://doi.org/10.5962/bhl.title.4635

Stamatakis, A. 2014. RAxML Version 8: A tool for phylogenetic analysis and post-analysis of large phylogenies. Bioinformatics 9: 1312-1313. https://doi.org/10.1093/bioinformatics/btu033

Sukumaran, J. \& Holder, M.T. 2010. DendroPy: A Python library for phylogenetic computing. Bioinformatics 26: 1569-1571. https://doi.org/10.1093/bioinformatics/btq228

Thiv, M., Thulin, M., Kilian, N. \& Linder, H.P. 2006. Eritreo-arabian affinities of the Socotran flora as revealed from the molecular phylogeny of Aerva (Amaranthaceae). Syst. Bot. 31: 560-570. https://doi.org/10.1600/036364406778388683

Tonti-Filippini, J., Nevill, P.G., Dixon, K. \& Small, I. 2017. What can we do with 1000 plastid genomes? Plant J. 90(4): 808-818. https://doi.org/10.1111/tpj.13491

Townsend, C.C. 1993. Amaranthaceae. Pp. 70-91 in: Kubitzki, K., Rohwer, J.G. \& Bittrich, V. (eds.), The families and genera of vasuclar plants, vol. 2. Berlin: Springer. https://doi.org/10.1007/978-3-662-028995 -7

Turland, N.J., Wiersema, J.H., Barrie, F.R., Greuter, W., Hawksworth, D.L., Herendeen, P.S., Knapp, S., Kusber, W.-H., Li, D.-Z., Marhold, K., May, T.W., McNeill, J., Monro, A.M., Prado, J., Price, M.J. \& Smith, G.F. (eds.) 2018. International Code of Nomenclature for algae, fungi, and plants (Shenzhen Code) adopted by the Nineteenth International Botanical Congress Shenzhen, China, July 2017. Regnum Vegetabile 159. Glashütten: Koeltz Botanical Books. https://doi.org/10.12705/Code.2018

Walker, B.J., Abeel, T., Shea, T., Priest, M., Abouelliel, A., Sakthikumar, S., Cuomo, C.A., Zeng, Q., Wortman, J., Young, S.K. \& Earl, A.M. 2014. Pilon: An integrated tool for comprehensive microbial variant detection and genome assembly improvement. PLoS ONE 9(11): e112963. https://doi.org/10.1371/journal.pone.0112963

Wei, R., Yan, Y., Harris, A., Kang, J., Shen, H., Xiang, Q. \& Zhang, X. 2017. Plastid phylogenomics resolve deep relationships among Eupolypod II Ferns with rapid radiation and rate heterogeneity. Genome Biol. Evol. 9(6): 1646-1657. https://doi.org/10.1093/gbe/evx107

Williams, A.V., Miller, J.T., Small, I., Nevill, P.G. \& Boykin, L.M. 2016. Integration of complete chloroplast genome sequences with small amplicon datasets improves phylogenetic resolution in Acacia. Molec. Phylogen. Evol. 96: 1-8. https://doi.org/10.1016/j.ympev.2015.11.021

Zerbino, D.R. \& Birney, E. 2008. Velvet: Algorithms for de novo short read assembly using de Bruijn graphs. Genome Res. 18(5): 821-829. http://doi.org/10.1101/gr.074492.107 
Appendix 1. Voucher information and GenBank accession numbers for taxa used in the Sanger dataset. Taxon names follow changes outlined in the taxonomic treatment. Taxon name, collection country (state), collector(s) and collection number (herbarium code), GenBank accession number for ITS (or ITS1 \& ITS2) and $m a t K$. An asterisk (*) indicates newly generated sequences for this study.

Achyranthes aspera L., Australia (Western Australia), R. Barrett 8308 (PERTH), KP875780, KP875780; Aerva javanica (Burm.f.) Juss. ex Schult., Australia (Western Australia), L. Hunt LH 20 (PERTH), KP875878, KP875781; Alternanthera pungens Kunth, U.S.A., T. Borsch, D. Pratt \& K. Müller 3449 (BONN, ISC), -, AY514795; Amaranthus caudatus L., Bolivia, Ames 13860 (BARC), KC747415, KC747132; Arthraerua leubnitizae Schinz, Namibia (Swakopmund), D. Long \& D. Rae 760 (E), MK013148*, MK013122*; Gomphrena flaccida R.Br., Australia (Western Australia), P. Courtney 203 (PERTH) KP875879, KP875782; Gomphrena kanisii J.Palmer, Australia (Western Australia), G. Byrne 2773 (PERTH), KP875880, KP875783; Nothosaerva brachiata (L.) Wight, Burkina Faso, Anonymous s.n. (FR), -, AY514806; Omegandra kanisii G.J.Leach \& C.C.Towns., Australia (Northern Territory), P. Jobson \& C. Martine 12480 (NT), MK013149*, MK013123*; Ouret congesta (Balf.f. ex Baker) Kuntze, Mauritius, Hansen s.n. (MAU), AJ829504 \& AJ829477, AJ833650; Ouret coriacea (Schinz) T.Hammer, Madagascar, Phillipson \& Rabes 3141 (WAG), AJ829506 \& AJ829506, AJ833651; Ouret glabrata (Hook.f.) Kuntze, China (Guizhou), S. Tan 0472 (PE), MK013150*, MK013124*; Ouret lanata (L.) Kuntze, Yemen (Socotra), M. Thiv 3118 (STU, Z), AJ829519 \& AJ829492, AJ833662; Ouret leucura (Moq.) Kuntze, Zimbabwe, Schneller 16 (Z), AJ829522 \& AJ829495, AJ833665; Ouret sanguinolenta (L.) Kuntze, Bhutan, Grierson \& Long 4536 (E), AJ829526 \& AJ829499, AJ833668; Ouret triangularifolia (Cavaco) T.Hammer, Madagascar, Randrianaivo 362 (MO), AJ829528 \& AJ829501, AJ833670; Paraerva microphylla (Moq.) T.Hammer, Yemen (Socotra), M. Thiv 3233 (STU, Z), AJ829524 \& AJ829497, AJ833666; Paraerva revoluta (Balf.f.) T.Hammer, Yemen (Socotra), M. Thiv 3179 (STU, Z), AJ829525 \& AJ829498, AJ833667; Ptilotus actinocladus T.Hammer \& R.W.Davis, Australia (Western Australia), G. Byrne 307 (PERTH) KP875954, KP875857; Ptilotus aervoides (F.Muell.) F.Muell., Australia (Western Australia), R. Davis, T. Hammer \& B. Anderson RD 12267 (PERTH), KP875881, KP875784; Ptilotus albidus (C.A.Gardner) Benl, Australia (Western Australia), K. Thiele 3289 (PERTH), KP875882, KP875785; Ptilotus alexandri Benl, Australia (Western Australia), C. Page DHI 78 (PERTH), KP875883, KP875786; Ptilotus andersonii R.W.Davis, Australia (Western Australia), S. Patrick 2787 (PERTH), -, MK013125*; Ptilotus angustifolius T.Hammer, Australia (South Australia), K. Brewer 895 (PERTH) MK013151*, MK013126*; Ptilotus aphyllus Benl, Australia (Western Australia), R. Davis 2007 (PERTH), KP875884, KP875787; Ptilotus appendiculatus Benl, Australia (Western Australia), R. Davis 11812 (PERTH), KP875885, KP875788; Ptilotus aristatus Benl subsp. aristatus, Australia (South Australia), R. Bates 58592 (AD), KP875886, KP875789; Ptilotus aristatus subsp. micranthus Albr. \& Lally, Australia (Northern Territory), G. Leach \& M. Leach 1851 (CANB), KP875887, KP875790; Ptilotus arthrolasius F.Muell., Australia (Western Australia), R. Davis 11821 (PERTH), KP875888, KP875791; Ptilotus astrolasius F.Muell., Australia (Western Australia), R. Davis 11795 (PERTH), KP875889, KP875792; Ptilotus auriculifolius (A.Cunn. ex Moq.) F.Muell., Australia (Western Australia), R. Davis 11815 (PERTH), KP875890, KP875793; Ptilotus axillaris (F.Muell. ex Benth.) F.Muell., Australia (Western Australia), R. Davis 11793 (PERTH), KP875891, KP875794; Ptilotus barkeri Benl, Australia (South Australia), E. James 153 (NT), MK013152*, MK013127*; Ptilotus beardii Benl, Australia (Western Australia), R. Davis 11343 (PERTH), KP875892, KP875795; Ptilotus beckerianus (F.Muell.) F.Muell. ex J.M.Black, Australia (South Australia), F. Davies 1432 (CBG), KP875893, KP875796; Ptilotus benlii R.W.Davis \& T.Hammer, Australia (Western Australia), R. Davis 10952 (PERTH), MK013153*, MK013128*; Ptilotus blackii Benl, Australia (Western Australia), R. Davis 11966 (PERTH), KP875894, KP875797; Ptilotus calostachyus F.Muell., Australia (Western Australia), R. Davis 11816 (PERTH) KP875895, KP875798; Ptilotus capensis (Benl) A.R.Bean, Australia (Queensland), D. Crayn \& S. Worboys 1346 (CNS), -, MK013129*; Ptilotus capitatus (F.Muell.) C.A.Gardner, Australia (Western Australia), G. Byrne 1642 (PERTH), KP875896, KP875799; Ptilotus carinatus Benl, Australia (Western Australia), D. Edinger 5125 (PERTH), KP875897, KP875800; Ptilotus carlsonii F.Muell., Australia (Western Australia), R. Meissner \& R. Coppen 4224 (PERTH), MK013154*, MK013130*; Ptilotus chamaecladus Diels, Australia (Western Australia), R. Davis, T. Hammer \& B. Anderson RD 12296 (PERTH), KP875898, KP875801; Ptilotus chippendalei Benl, Australia (Western Australia), R. Chinnock 572 (AD), KP875899, KP875802; Ptilotus chortophytus (Diels) Schinz Australia (Western Australia), R. Davis 10923 (PERTH), KP875900, KP875803; Ptilotus chrysocomus R.W.Davis, Australia (Western Australia), J. Williams s.n. (PERTH) KP875901, KP875804; Ptilotus clementii (Farmar) Benl, Australia (Western Australia), R. Davis 11817 (PERTH), KP875902, KP875805; Ptilotus clivicola R.W.Davis \& T.Hammer, Australia (Western Australia), C. Payne s.n. (PERTH), KP875903, KP875806; 
Ptilotus comatus Benl, Australia (Northern Territory), K. Brennan 10363 (DNA), MK013155*, MK013131*; Ptilotus conicus R.Br., Australia (Western Australia), R. Barrett \& M. Barrett 3134 (PERTH), KP875904, KP875807; Ptilotus corymbosus R.Br., Australia (Western Australia), G. Byrne 3400 (PERTH), KP875905, KP875808; Ptilotus crispus Benl, Australia (Western Australia), R. Barrett \& M. Barrett 3156 (PERTH), KP875906, KP875809; Ptilotus crosslandii (F.Muell. ex Oliv.) Benl, Australia (Western Australia), R. Davis, T. Hammer \& B. Anderson RD 12286 (PERTH), KP875907, KP875810; Ptilotus daphne Lally, Australia (Western Australia), N. Gibson 6505 (PERTH), KP875908, KP875811; Ptilotus decalvatus Benl, Australia (Western Australia), P. Chukowry BES PC 039 (PERTH), KP875909, KP875812; Ptilotus decipiens (Benth.) C.A.Gardner, Australia (Western Australia), D.J. Edinger 1870 (PERTH), KP875910, KP875813; Ptilotus declinatus Nees Australia (Western Australia), R. Davis \& P. Jobson RD 12004 (PERTH), KP875911, KP875814; Ptilotus disparilis Lally, Australia (South Australia), K. Brewer 722 (AD), MK013156*, MK013132*; Ptilotus dissitiflorus (F.Muell.) F.Muell., Australia (Northern Territory), P. Jobson 11869 (NT), -, MK013133*; Ptilotus distans (R.Br.) Poir., Australia (Western Australia), R. Barrett 737 (PERTH), KP875912, KP875815; Ptilotus divaricatus (Gaudich.) F.Muell., Australia (Western Australia), T. Hammer \& R. Davis TH 71 (PERTH), MK013157*, MK013134*; Ptilotus drummondii (Moq.) F.Muell., Australia (Western Australia), G. Byrne 2040 (PERTH), KP875913, KP875816; Ptilotus eremita (S.Moore) T.Hammer \& R.W.Davis, Australia (Western Australia), R. Davis 12114 (PERTH), KP875921, KP875824; Ptilotus eriotrichus (W.Fitzg. ex Ewart \& J.White) P.S.Short, Australia (Western Australia), I. Fordyce MU 55-37 (PERTH) KP875914, KP875817; Ptilotus erubescens Schltdl., Australia (South Australia), K. Graham BS117-1227 (AD), MK013158*, MK013135*; Ptilotus esquamatus (Benth.) F.Muell., Australia (Western Australia), R. Davis 11292 (PERTH), KP875915, KP875818; Ptilotus exaltatus Nees, Australia (Western Australia), R. Davis, T. Hammer \& B. Anderson RD 12295 (PERTH), KP875945, KP875848; Ptilotus exiliflorus R.W.Davis, Australia (Western Australia), J. Firth 692 (PERTH), KP875916, KP875819; Ptilotus falcatus R.W.Davis \& T.Hammer, Australia (Western Australia), R. Warner \& S. Werner WWF 12-14 (PERTH), KP875917, KP875820; Ptilotus fasciculatus W.Fitzg. Australia (Western Australia), J. Richardson s.n. (PERTH 07292767), KP875918, KP875821; Ptilotus fusiformis (R.Br.) Poir., Australia (Western Australia), R. Davis \& R. Butcher RD 11819 (PERTH), KP875919, KP875822; Ptilotus gardneri Benl, Australia (Western Australia), R.W. Purdie 4895 (PERTH), KP875920, KP875823; Ptilotus gaudichaudii (Steud.) J.M.Black, Australia (Western Australia), R. Davis, T. Hammer \& B. Anderson RD 12283 (PERTH), KP875922, KP875825; Ptilotus giganteus (A.Cunn. ex Moq.) R.W.Davis \& R.Butcher, Australia (Western Australia), K.F. Kenneally K 11831 (PERTH), KP875924, KP875827; Ptilotus gomphrenoides F.Muell. ex Benth., Australia (Western Australia), R. Davis, T. Hammer \& B. Anderson RD 12280 (PERTH), KP875925, KP875828; Ptilotus grandiflorus F.Muell., Australia (Western Australia), M. Trudgen \& M. Guest 22546 (PERTH) KP875926, KP875829; Ptilotus halophilus R.W.Davis, Australia (Western Australia), I. Fordyce KL 25-1 (PERTH) KP875927, KP875830; Ptilotus helichrysoides (F.Muell.) F.Muell., Australia (Western Australia), J. Jackson, A. Brown \& B. Moyle DLP 128 (PERTH), KP875928, KP875831; Ptilotus helipteroides (F.Muell.) F.Muell., Australia (Western Australia), R. Davis, T. Hammer \& B. Anderson RD 12274 (PERTH), KP875929, KP875832; Ptilotus holosericeus (Moq.) F.Muell., Australia (Western Australia), R. Davis 11829 (PERTH), KP875930, KP875833; Ptilotus humilis (Nees) F.Muell., Australia (Western Australia), R. Davis 12361 (PERTH), KP875931, KP875834; Ptilotus incanus (R.Br.) Poir., Australia (Western Australia), P. Hurter WP15 (PERTH), KP875932, KP875835; Ptilotus indivisus Benl, Australia (New South Wales), T. Lally 1675 (CANB), MK013159*, MK013136*; Ptilotus johnstonianus W.Fitzg., Australia (Western Australia), H. Dauncey H337 (PERTH), KP875933, KP875836; Ptilotus kenneallyanus Benl, Australia (Western Australia), G. Byrne 1484 (PERTH), KP875934, KP875837; Ptilotus lanatus A.Cunn. ex Moq., Australia (Western Australia), G. Byrne 1349 (PERTH), MK013160*, MK013137*; Ptilotus latifolius R.Br., Australia (Western Australia), R. Davis 11791 (PERTH), KP875935, KP875838; Ptilotus lazaridis Benl, Australia (Western Australia), P. Hurter s.n. (PERTH 08406812), KP875936, KP875839; Ptilotus leucocoma (Moq.) F.Muell., Australia (New South Wales), R. Purdie 7832 (CANB), KP875937, KP875840; Ptilotus lophotrichus Benl, Australia (Northern Territory), K. Brennan 9293 (DNA), MK013161*, MK013138*; Ptilotus luteolus (Benl \& H.Eichler) R.W.Davis, Australia (Western Australia), S. Kern \& D. True 12043 (PERTH), MK013162*, MK013139*; Ptilotus maconochiei Benl, Australia (Queensland), D. Kelman 141 (BRI), KP875938, KP875841; Ptilotus macrocephalus (R.Br.) Poir., Australia (Western Australia), R. Davis 11787 (PERTH), KP875939, KP875842; Ptilotus manglesii (Lindl.) F.Muell., Australia (Western Australia), R. Davis \& P. Jobson RD 12005 (PERTH), KP875940, KP875843; Ptilotus marduguru Benl, Australia (Western Australia), Sweedman LSJ 6574 (PERTH), KP875941, KP875844; Ptilotus mitchellii Benl, Australia (Western Australia), E. Thoma ET 1335 (PERTH), KP875942, KP875845; Ptilotus modestus T.Hammer, Australia (New South Wales), R. Purdie 7847 (CANB), KP875923, 
KP875826; Ptilotus mollis Benl, Australia (Western Australia), J. Bull ONS JSF 338.02 (PERTH), KP875943, KP875846; Ptilotus murrayi F.Muell., Australia (Western Australia), K. Thiele 4583 (PERTH), KP875944, KP875847; Ptilotus nobilis (Lindl.) F.Muell., Australia (South Australia), T. Hammer \& K. Thiele TH 84 (PERTH), MK013163*, MK013140*; Ptilotus obovatus (Gaudich.) F.Muell., Australia (Western Australia), R. Davis, T. Hammer \& B. Anderson RD 12268 (PERTH), KP875947, KP875850; Ptilotus parvifolius (F.Muell.) F.Muell., Australia (South Australia), D. Duval 17 (AD),-, MK013141*; Ptilotus pedleyanus Benl \& H.Eichler, Australia (Queensland), J. Silcock JLS680 (BRI), KP875948, KP875851; Ptilotus polakii subsp. iuxtus Lally, Australia (Western Australia), R. Davis 11797 (PERTH), KP875949, KP875852; Ptilotus polakii F.Muell. subsp. polakii, Australia (Western Australia), R. Davis 11788 (PERTH), KP875950, KP875853; Ptilotus polystachyus (Gaudich.) F.Muell., Australia (Western Australia), R. Davis 12276 (PERTH), KP875951, KP875854; Ptilotus procumbens Benl Australia (Western Australia), P. Armstrong 06/860 (PERTH), KP875952, KP875855; Ptilotus propinquus Lally, Australia (South Australia), H. Vonow 2184 (AD), KP875953, KP875856; Ptilotus pyramidatus (Moq.) F.Muell., Australia (Western Australia), C. Tauss 4102 (PERTH), KP875955, KP875858; Ptilotus remotiflorus Benl, Australia (Queensland), A. Emmott B689A (BRI) KP875956, KP875859; Ptilotus rigidus Lally, Australia (Western Australia), J. Jackson 290 (PERTH) KP875957, KP875860; Ptilotus roei (F.Muell. ex Benth.) F.Muell., Australia (Western Australia), R. Davis, T. Hammer \& B. Anderson RD 12277 (PERTH), KP875958, KP875861; Ptilotus rotundatus Benl, Australia (Northern Territory), K. Brennan 9109 (DNA), MK013164*, MK013142*; Ptilotus rotundifolius (F.Muell.) F.Muell., Australia (Western Australia), R. Davis, T. Hammer \& B. Anderson RD 12288 (PERTH), KP875959, KP875862; Ptilotus royceanus (Benl), Australia (Northern Territory), P. Jobson 10779 (NT), KP875960, KP875863; Ptilotus schwartzii (F.Muell.) Tate, Australia (Western Australia), R. Davis, T. Hammer \& B. Anderson RD 12273 (PERTH), KP875961, KP875864; Ptilotus semilanatus (Lindl.) J.M.Black, Australia (New South Wales), R. Purdie 7814 (CANB), KP875946, KP875849; Ptilotus seminudus (J.M.Black) J.M.Black, Australia (Western Australia), G. Cockerton \& N. McQuoid LCH 15892 (PERTH), KP875962, KP875865; Ptilotus sericostachyus (Nees) F.Muell., Australia (Western Australia), R. Davis 11298 (PERTH), KP875963, KP875866; Ptilotus sessilifolius (Lindl.) Benl, Australia (Western Australia), R. Cranfield 21749 (PERTH), KP875964, KP875867; Ptilotus sp. Arckaringa (D.J.Duval 1958), Australia (South Australia), D. Duval 1958 (AD), -, MK013143*; Ptilotus spathulatus (R.Br.) Poir., Australia (Western Australia), W. Thompson \& J. Allen 1445 (PERTH), KP875965, KP875868; Ptilotus spicatus F.Muell. ex Benth., Australia (Western Australia), G. Byrne 3052 (PERTH), KP875966, KP875869; Ptilotus stipitatus Benl, Australia (Western Australia), R. Davis 11184 (PERTH), KP875967, KP875870; Ptilotus stirlingii subsp. australis R.W.Davis \& R.Butcher, Australia (Western Australia), R. Davis 10956 (PERTH), KP875968, KP875871; Ptilotus stirlingii (Lindl.) F.Muell. subsp. stirlingii, Australia (Western Australia), R. Davis 10956 (PERTH), KP875969, KP875872; Ptilotus subspinescens R.W.Davis, Australia (Western Australia), E. Thoma \& A. Joder 145 (PERTH), KP875970, KP875873; Ptilotus symonii Benl, Australia (Western Australia), K. Thiele 3722 (PERTH) KP875971, KP875874; Ptilotus trichocephalus Benl, Australia (Western Australia), R. Davis 10988 (PERTH), KP875972, KP875875; Ptilotus uncinellus (A.R.Bean) T.Hammer, Australia (Queensland), B. Thomson s.n. (BRI AQ0830746), MK013165*, MK013144*; Ptilotus villosiflorus F.Muell., Australia (Western Australia), T. Hammer, S. Dillon \& K. Thiele TH 24 (PERTH), MK013166*, MK013145*; Ptilotus whitei (J.M.Black) Lally, Australia (Western Australia), P. Jobson 10452 (NT), KP875973, KP875876; Ptilotus wilsonii Benl, Australia (Western Australia), H. Adjuk HA 75 (PERTH), MK013167*, MK013146*; Ptilotus yapukaratja R.W.Davis \& T.Hammer, Australia (Western Australia), M. Griffiths \& S. Cherriman s.n. (PERTH 08513848), MK013168*, MK013147*; Wadithamnus artemisioides (Vierh. \& O.Schwartz) T.Hammer \& R.W.Davis, Yemen (Al Mahra), Kilian 6882 (B), AJ829477 \& AJ829504, AJ833649. 
Appendix 2. Voucher information and GenBank accession numbers for taxa used in the CDS dataset. Taxon names follow changes outlined in the taxonomic treatment. Taxon name, collection country (state), collector(s) and collection number (herbarium code), and GenBank accession number. All accessions were newly sequenced for this study.

Achyranthes aspera L., Australia (Western Australia), S. Dillon \& A. Markey CR 9167 (PERTH), MK410010; Aerva javanica (Burm.f.) Juss. ex Schult., Australia (Western Australia), T. Hammer, S. Dillon \& K. Thiele TH 26 (PERTH), MK410028; Alternanthera nodiflora R.Br., Australia (Western Australia), S. van Leeuwen \& al. PBS 0410 (PERTH), MK410015; Amaranthus cuspidifolius Domin, Australia (Western Australia), B. Mathews \& R. Orifici BES BDM 029 (PERTH), MK410001; Gomphrena affinis subsp. pilbarensis Kanis ex J.Palmer, Australia (Western Australia), C. Flaherty \& E. Ridley CEF 064 (PERTH), MK410012; Gomphrena cunninghamii (Moq.) Druce, Australia (Western Australia), T. Edwards 38 (PERTH), MK410014; Omegandra kanisii G.J.Leach \& C.C.Towns., Australia (Northern Territory), P. Jobson 12480 (NT), MK410034; Ouret glabrata (Hook.f.) Kuntze, China (Guizhou), S. Tan 0472 (PE), MK410031; Paraerva microphylla (Moq.) T.Hammer, Yemen (Socotra), A. Miller 10287 (E), MK410032; Ptilotus aervoides (F.Muell.) F.Muell., Australia (Western Australia), T. Hammer \& S. Dillon TH 28 (PERTH), MK410022; Ptilotus appendiculatus Benl, Australia (Western Australia), T. Hammer \& S. Dillon TH 50 (PERTH), MK410029; Ptilotus arthrolasius F.Muell., Australia (Western Australia), S. Dillon \& A. Markey CR 9154 (PERTH), MK410016; Ptilotus astrolasius F.Muell., Australia (Western Australia), T. Hammer, S. Dillon \& K. Thiele TH 23 (PERTH), MK410023; Ptilotus auriculifolius (A.Cunn. ex Moq.) F.Muell., Australia (Western Australia), A.R. Bean 24989 (PERTH), MK410002; Ptilotus axillaris (F.Muell. ex Benth.) F.Muell., Australia (Western Australia), S. Dillon \& A. Markey CR 9151 (PERTH), MK410008; Ptilotus calostachyus F.Muell., Australia (Western Australia), T. Hammer, S. Dillon \& K. Thiele TH 18 (PERTH), MK410030; Ptilotus chamaecladus Diels, Australia (Western Australia), T. Hammer \& S. Dillon TH 53 (PERTH), MK410025; Ptilotus clementii (Farmar) Benl, Australia (Western Australia), B. Morgan Bmor 1067 (PERTH), MK409999; Ptilotus divaricatus (Gaudich.) F.Muell., Australia (Western Australia), T. Hammer \& R. Davis TH 71 (PERTH), MK410020; Ptilotus drummondii (Moq.) F.Muell., Australia (Western Australia), T. Hammer \& R. Davis TH 75 (PERTH), MK410021; Ptilotus erubescens Schltdl., Australia (South Australia), K. Graham BS117-1227 (AD), MK410035; Ptilotus exaltatus Nees, Australia (Western Australia), A.R. Bean 25246 (PERTH), MK410003; Ptilotus fusiformis (R.Br.) Poir., Australia (Western Australia), S. Dillon \& A. Markey CR9156 (PERTH), MK409998; Ptilotus gaudichaudii (Steud.) J.M.Black, Australia (Western Australia), S. van Leeuwen 3866 (PERTH), MK410004; Ptilotus gomphrenoides F.Muell. ex Benth., Australia (Western Australia), K. McMaster LCH 25882 (PERTH), MK410011; Ptilotus helipteroides (F.Muell.) F.Muell., Australia (Western Australia), K. Thiele 4145 (PERTH), MK410007; Ptilotus latifolius R.Br., Australia (Western Australia), T. Hammer \& S. Dillon TH 49 (PERTH), MK410027; Ptilotus macrocephalus (R.Br.) Poir., Australia (Western Australia), B. Morgan Bmor 1076 (PERTH), MK410037; Ptilotus mollis Benl, Australia (Western Australia), S. Coultas SC 12 (PERTH), MK410005; Ptilotus obovatus (Gaudich.) F.Muell., Australia (Western Australia), A. Douglas \& R. Graham LCH 14916 (PERTH), MK410006; Ptilotus polakii subsp. juxtus Lally, Australia (Western Australia), T. Hammer \& S. Dillon TH 51 (PERTH), MK410024; Ptilotus polystachyus (Gaudich.) F.Muell., Australia (Western Australia), A.R. Bean 25397 (PERTH), MK419082; Ptilotus pyramidatus (Moq.) F.Muell., Australia (Western Australia), C. Tauss 4102 (PERTH), MK410036; Ptilotus roei (F.Muell. ex Benth.) F.Muell., Australia (Western Australia), R. Davis, T. Hammer \& B. Anderson RD 12277 (PERTH), MK410017; Ptilotus rotundifolius (F.Muell.) F.Muell., Australia (Western Australia), G. Cassis PILB 202 (PERTH), MK410000; Ptilotus schwartzii (F.Muell.) Tate, Australia (Western Australia), B. Vincent BV 108 (PERTH), MK410013; Ptilotus subspinescens R.W.Davis, Australia (Western Australia), M. Trudgen \& P. Chukowry BES PC 054 (PERTH), MK410009; Ptilotus trichocephalus Benl, Australia (Western Australia), R. Davis \& F. Obbens RD 12329 (PERTH), MK410018; Ptilotus uncinellus A.R.Bean, Australia (Queensland), B. Thomson s.n. (BRI: AQ0830743), MK410033; Ptilotus villosiflorus F.Muell., Australia (Western Australia), T. Hammer, S. Dillon \& K. Thiele TH 24 (PERTH), MK410026; Ptilotus wilsonii Benl, Australia (Western Australia), H. Adjuk HA 75 (PERTH), MK410019. 
Appendix 3. Selected specimens examined from the major clades within the aervoids for the morphological examinations. Taxon names follow changes outlined in taxonomic treatment.

Aerva javanica (Burm.f.) Juss. ex Schult. - AFRICA. Egypt, Aswan, Abraq area, 6 March 1986, Sheded 3254 (E: E00161900). ASIA. Iran, Kerman, Esfandaqeh to Jiroft, $25 \mathrm{~km}$ W to Jiroft (Sabzvaran), 11 June 1977, Assadi \& al. 1893 (E: E00161898); United Arab Emirates, Abu Dhabi, Wadi Mubarraz SE of Al Ayn at Zoological Gardens, 19 February 1980, Edmondson 3055 (E: E00687230). AUSTRALIA. Western Australia, Pilbara, Roadside $100 \mathrm{~m}$ E of Turner River, on Great Northern Highway $18 \mathrm{~km} \mathrm{SW}$ of South Hedland, 18 August 2015, Hammer \& al. TH26 (PERTH: PERTH 08743924). Nothosaerva brachiata (L.) Wight ASIA. India, Punjab, "Karnal Jungle”, 29 November 1886, Drummond 26464 (E: E00732824); Sri Lanka, North Central Province, Anuradhapura District, roadside 100 miles from Kandy on road to Jaffna, S of Punawa, 24 February 1973, Townsend 73/115 (E: E00732826); E of the road from Dambulla to Anuradhapura [at] milestone 53, 8 March 1973, Townsend 73/181 (E: E00732828). Omegandra kanisii G.J.Leech \& C.C.Towns. - AUSTRALIA. Northern Territory, Batten Point, near junction of Batten Creek and McArthur River, 45 km NNE of Borroloola, 13 May 2016, Jobson \& Martine 12480 (NT: D0273611); Queensland, 2 km east of Burketown, 10 May 2003, Thompson \& Newton BUR103 (BRI: AQ 769593); Frog site waterhole, N of Normanton on Burke development road, 30 April 2004, McDonald KRM2274 (BRI: BRI-AQ766448). Ouret glabrata (Hook.f.) Kuntze - ASIA. China, Guizhou Province, Ceheng, Zhe Lou Zhen, 7 August 2004, Wang 0333 (PE: PE00874853); Zhenfeng, Lianhuan Xiang, 5 June 2005, Tan 0472 (PE: PE01522637); Yunnan, Mengzi, Jinpo temple, 21 November 2003, Shui \& al. 40525 (PE: PE01869486). Ouret lanata (L.) Kuntze - ASIA. Sri Lanka, Anuradhapura District, Aukana, 17 February 1973, Townsend 73/65 (E: E00732833); Yemen, Socotra Wadi Deneghan, 7 km SE of Hadiboh, 19 February 1989, Miller \& al. 8246 (E: E00161942). AFRICA. South Africa, Natal [KwaZulu-Natal Prov.], Dunford Native Reserve, 5 September 1970, Strey 9917 (E: E00732832). Ouret leucura (Moq.) Kuntze - AFRICA. Botswana, Ngamiland District, $8.5 \mathrm{~km} \mathrm{~W}$ of Tsau [Tsao], 13 March 1987, Long \& Rae 248 (E: E00161939); Moremi road between south gate and main road, 24 March 1987, Long \& Rae 439 (E: E00161938). Ouret sanguinolenta (L.) Kuntze - ASIA. Bhutan, Punakha District, near Wache, Tang Chu, 20 April 1982, Grierson \& Long 4536 (E: E00161940); China, Guangxi, Yangshou Park, 19 October 1988, Skyes Ch548 (E: E00271791); Taiwan, Pingtung Hsien, Chunjih Hsiang, Tahan forest road, 4 December 1994, Hsiao \& al. 1007 (E: E00025998). Paraerva microphylla (Moq.) T.Hammer - ASIA. Yemen, Socotra, Wadi Irih draining S into Nogad plain due S of Hadiboh, 28 February 1989, Miller \& al. 8524 (E: E00161904); Nogad plain, mouth of Wadi Irih, 5 February 1990, Miller \& al. 10287 (E: E00161903). Paraerva revoluta (Balf.f.) T.Hammer - ASIA. Yemen, Socotra, Mugadrihon Pass, 5 km SSW of Hadiboh, 21 February 1989, Miller \& al. 8297 (E: E00161902); Wadi Daneghan, $10 \mathrm{~km}$ SE of Hadiboh, 10 February 1990, Miller \& al. 10377 (E: E00161901); Mugadrihon Pass, 28 January 1994, Thulin \& Gifri 8809 (E: E00687203). Ptilotus aervoides (F.Muell.) F.Muell. AUSTRALIA. Western Australia, Pilbara, Powerline track S off Rio Tinto Rail Access Road $\sim 250 \mathrm{~m}$ N of Fortescue River, 19 August 2015, Hammer \& Dillon TH 28 (PERTH: PERTH 08735123). Ptilotus astrolasius F.Muell. - AUSTRALIA. Western Australia, Pilbara, $300 \mathrm{~m} \mathrm{~S}$ of intersection with the North West Coastal Highway, $26 \mathrm{~km}$ SW of South Hedland, 16 August 2015, Hammer \& al. TH 23 (PERTH: PERTH 08735301). Ptilotus appendiculatus Benl - AUSTRALIA. Western Australia, Pilbara, on the roadside of North West Coastal Highway, $14 \mathrm{~km} \mathrm{SW}$ of Nanutarra Roadhouse, 22 August 2015, Hammer \& Dillon TH 50 (PERTH: PERTH 08743940). Ptilotus decipiens (Benth.) C.A.Gardner - AUSTRALIA. Western Australia, Central Ranges, camp 1 at Townsend Ridges, $42 \mathrm{~km}$ SE of Warburton, 6 May 2000, Edinger 1870 (PERTH: PERTH 05619289); 3 km W of Mount Webb, 17 July 2016, Trickett DD966 (PERTH: PERTH 08854165). Ptilotus divaricatus (Gaudich.) F.Muell. - AUSTRALIA. Western Australia, Jibberding Natural Area Reserve parking bay $25 \mathrm{~km}$ N of Wubin, 30 August 2015, Hammer \& Davis TH 71 (PERTH: PERTH 08619654). Ptilotus drummondii (Moq.) F.Muell. - AUSTRALIA. Western Australia, Chittering, $19.5 \mathrm{~km} \mathrm{E}$ along BindoonDewars Pool Road from Great Northern Highway, 25 October 2015, Hammer \& Davis TH 75 (PERTH: PERTH 08619476). Ptilotus erubescens Schltdl. - AUSTRALIA. South Australia, Barossa, [4.2 km direct WNW of Williamstown], 25 October 2000, Graham \& Kajar BS117-1227 (AD: AD 154486). Ptilotus exaltatus Nees - AUSTRALIA. Western Australia, Pilbara, $54 \mathrm{~km}$ from Newman on road to Marble Bar, 1 May 2006, Bean 25246 (PERTH: PERTH 07484038). Ptilotus helipteroides (F.Muell.) F.Muell. AUSTRALIA. Western Australia, De La Poer Range Nature Reserve, Dumbung Soak, 24 April 2011, Thiele 4145 (PERTH: PERTH 08430225). Ptilotus mollis Benl - AUSTRALIA. Western Australia, Pilbara, Ironstone hill slope $270 \mathrm{~m}$ ESE of Marble Bar Road, $55 \mathrm{~km} \mathrm{SE}$ of Marble Bar and $208 \mathrm{~km}$ SE of Port Hedland, 29 April 2013, Coultas SC 12 (PERTH: PERTH 08568863). Ptilotus polakii subsp. juxtus Lally AUSTRALIA. Western Australia, Carnarvon, On track $2 \mathrm{~km}$ E of North West Coastal Highway and $11.4 \mathrm{~km}$ 
SSE of Minilya roadhouse, 22 August 2015, Hammer \& Dillon TH 51 (PERTH: PERTH 08743762). Ptilotus polystachyus (Gaudich.) F.Muell. - AUSTRALIA. Western Australia, Mid West region, $80 \mathrm{~km} \mathrm{~N}$ of Mullewa, 29 August 2015, Hammer \& Davis TH 64 (PERTH: PERTH 08619611). Ptilotus rotundifolius F.Muell. AUSTRALIA. Western Australia, Junction of Great Northern Highway and Karijini Drive, 31 August 2005, Cassis PILB 202 (PERTH: PERTH 07273231). Ptilotus subspinescens R.W.Davis - AUSTRALIA. Western Australia, Pilbara, $35.91 \mathrm{~km}$ NW Mt Turner, $38.27 \mathrm{~km} \mathrm{SW} \mathrm{Mt} \mathrm{Sheila,} 62.17 \mathrm{~km}$ NW of Tom Price, Trudgen \& Chukowry BES-PC054 (PERTH: PERTH 08377200). Ptilotus uncinellus (A.R.Bean) T.Hammer AUSTRALIA. Queensland [precise localities withheld for conservation reasons], Collinsville, 25 June 2011, Thomson s.n. (BRI: BRI-AQ830743); Collinsville, 26 June 2011, Thomson s.n. (BRI: BRI-AQ0830746). Ptilotus villosiflorus F.Muell. - AUSTRALIA. Western Australia, Pilbara, On a sand dune on Pretty Pool Beach near the "clothing optional" sign, 17 August 2015, T. Hammer, S. Dillon \& K. Thiele TH 24 (PERTH: PERTH 08743886). 